\title{
There is No Evidence that Mandatory IFRS Adoption Significantly Decreased IPO Underpricing
}

\author{
Donal Byard* \\ and \\ Masako Darrough \\ Baruch College -- CUNY \\ Jangwon Suh \\ New York Institute of Technology
}

September 2019

\begin{abstract}
A recently published study (Hong, Hung, and Lobo, The Accounting Review 2014) claims to show that, depending on the benchmark sample used, the 2005 mandatory adoption of IFRS is associated with a $38-82 \%$ reduction in IPO underpricing. We re-examine this result controlling for the concurrent adoption of the Prospectus Directive (PD), which mandated increased IPO prospectus disclosures, and the enforcement of these disclosures in the member states of the European Union (EU). First, we find that there is a significant data error in Hong et al.'s study that renders their reported results unreliable: approximately $30 \%$ of the treatment firms this study categorizes as mandatory IFRS adoptions are not, in fact, subject to a mandate to report in IFRS. These are firms admitted to trading on "exchangeregulated" markets in the EU that do not require IFRS. We use hand-collected prospectus data to identify the correct treatment sample. Our analysis shows that, for affected firms, there is a statistically significant decrease in IPO underpricing associated with adoption of the PD for firms based in countries that also concurrently enhanced accounting enforcement (see Christensen, Hail, and Leuz 2013), but there is no association between mandatory IFRS adoption and IPO underpricing. We also examine voluntary IFRS adoptions by firms admitted to trading on exchange-regulated markets after 2005. Overall we find no evidence that mandatory IFRS adoption resulted in very large economic gains for IPO firms. This study also provides a brief but comprehensive description of much of EU capital markets law.
\end{abstract}

Keywords: Mandatory IFRS adoption, IPO Underpricing, European Union, Prospectus Directive, EU-Regulated Market, Exchange-Regulated Market

\footnotetext{
* Corresponding author: donal.byard@baruch.cuny.edu and 646-312-3187. We gratefully acknowledge helpful input and comments on earlier versions of this paper from Christof Beuselinck, Massimiliano Bonacchi, Matthias Breuer, Anna Brown, Ulf Brüggemann, Hans Christensen, Luzi Hail, Kathleen Weiss Hanley, Phillip Joos, Edith Leung, Christian Leuz, Antonio Marra, Jochen Pierk, Peter Pope, Grace Pownall, Jay Ritter, Amanda Sanseverino, Andy Stark, Maria Wieczynska, and Steve Zeff. We also thank Oskar Wollert (AktieTorget, Sweden), Asimina Zagka (Athens Stock Exchange), Clément Tallee and Cecilia Marguin (Euronext), Orla O'Gorman and James Ferguson (Irish Stock Exchange), Jimmy Kvarnström and Håkan Sjögren (Nasdaq Nordic), Lars Jacob Braarud, Carina Østlin and Kjell Vidjeland (Oslo Børs), Silvia Stenitzer (Vienna Stock Exchange), and Joyce Favia (Thomson Reuters) for help with institutional details.
} 


\section{Introduction}

The 2005 mandatory adoption of International Financial Reporting Standards (IFRS) in a large number of countries, including the member states of the European Union (EU), is the single largest change in accounting regulation in recent decades. Not surprisingly, a large empirical literature focuses on documenting the economic consequences of this regulatory change. ${ }^{1}$ As part of this literature, a recently published study (Hong, Hung, and Lobo, The Accounting Review2014; hereafter "HHL") examines the association between the 2005 mandatory adoption of IFRS and Initial Public Offering (IPO) underpricing. HHL argue that "the improved disclosure and financial statement comparability associated with mandatory IFRS adoption reduce information asymmetry, which in turn reduces a firm's need to underprice an IPO” (HHL, p. 1381).

HHL use a sample of IPOs based in 20 countries. Using differences-in-differences (DID) tests, HHL compare the change in IPO underpricing between the pre- (2003-2004) and post- (20062007) mandatory IFRS adoption periods across a treatment sample of IPOs based in "IFRS adopting countries" and three benchmark samples of IPOs based in "non-IFRS adopting countries." The treatment sample consists of all IPOs in the period 2006-2007 in countries that adopted IFRS in 2005 and are dominated by firms based in the member states of the EU. The benchmark firms are IPOs over the same time period by firms based in countries that had not, as of the end of 2007, mandated IFRS adoption for domestic listed firms. HHL report that, between the pre- and post-IFRS adoption periods, mandatory IFRS adoption is associated with a statistically significant decrease in IPO underpricing in their treatment sample relative to the benchmark samples. The decrease is also economically very large: depending on the benchmark sample used, it represents a 38-82\% decrease in IPO underpricing, on average (see HHL, p. 1367).

We re-examine this result. The title of HHL's study "The impact of mandatory IFRS adoption on IPOs in Global Capital Markets" (emphasis added) suggests a causal relationship. A priori, however, it is difficult to believe that mandatory IFRS adoption per se could cause such a

\footnotetext{
${ }^{1}$ See Brüggemann, Hitz, and Sellhorn (2013), ICAEW (2015), De George, Li, and Shivakumar (2016), Leuz and Wysocki (2016) for reviews.
} 
large reduction in IPO underpricing. Understanding whether or not mandatory IFRS adoption actually caused such a dramatic reduction in IPO underpricing is obviously an important question for policymakers (see Gow, Larcker, and Reiss 2016; Leuz and Wysocki 2016). To clarify, HHL's results suggest that using one type of accounting standards (i.e., IFRS) vs. another (i.e., domestic GAAP) is associated with a $38-82 \%$ reduction in IPO underpricing, on average. Evidence from the reporting incentives literature, however, suggests that a decrease in IPO underpricing of this magnitude is unlikely to be caused by mandatory IFRS adoption per se. In particular, the reporting incentives literature shows that accounting standards play a limited role in determining observed reporting quality; instead, these studies point to the importance of firms' reporting incentives in determining observed reporting outcomes (e.g., see Ball, Robin, and Wu 2003; Leuz 2003; Ball and Shivakumar 2005; Burgstahler, Hail, and Leuz 2006). The international accounting literature further shows that firms' reporting incentives are shaped by the country-level institutional environment (e.g., Ball 2006; Leuz, Nanda, and Wysocki 2003).

Regulatory and institutional changes adopted concurrently with mandatory IFRS adoption can play a potentially important role in changing firms' reporting incentives and, hence, affecting economic outcomes. Christensen, Hail, and Leuz (2013) show that changes in liquidity around mandatory IFRS adoption are largely due to concurrent regulatory changes-specifically, increased accounting enforcement in a number of IFRS-adopting countries. Importantly, in the case of the IPO setting, there are a number of concurrent regulatory changes that potentially affected IPO firms' reporting incentives, but which have been overlooked by HHL. Specifically, the adoption in 2004 of the EU's Markets in Financial Instruments Directive, allowed for the development after 2005 of two distinct forms of markets for trading stocks: "EU-regulated" markets and "exchange-regulated" markets in Europe. Only EU-regulated markets were subject to EU capital markets directives, including the IFRS Directive, which mandated IFRS adoption from 2005. The new exchange-regulated markets were exempt from the EU's IFRS Directive and could decide for themselves whether to require IFRS. Most exchange-regulated markets have chosen not to require IFRS (see Appendix); therefore, firms admitted to trading on most exchange-regulated 
markets after 2005 could choose to use IFRS or domestic GAAP. Most choose to use domestic GAAP (see section 6).

After 2005, there was a proliferation of new exchange-regulated markets and a bifurcation in the types of domestic listing markets available to IPO firms in many EU member states. For example, before 2005, a German firm going public could list on a domestic stock market, all of which were under the same domestic regulatory framework. After 2005, however, a German firm could choose (1) to list on a domestic EU-regulated market, and be subject to the provisions of the EU capital markets directives, including the IFRS directive, or (2) to be admitted to trading on a new less regulated domestic exchange-regulated market (The Entry Standard, founded in 2005), and not be subject to the provisions of EU capital markets directives, including the IFRS Directive. If a German IPO firm chose option (2), then it could use either German GAAP or IFRS (but, if it uses IFRS, this is a voluntary IFRS adoption - see Pierk 2018). The newly developed exchangeregulated markets were designed to encourage the admission of smaller growth firms to trading in public capital markets.

Adoption of the EU's Prospectus Directive (the PD) is also likely to have affected the European IPO market and IPO firms' reporting incentives. The PD came into effect on different dates in the different member states of the EU, over the period 2005-2007, i.e., during HHL's sample period. This directive increased and harmonized the mandated disclosures required for IPO prospectuses issued by firms going public on EU-regulated markets (which would affect HHL's treatment sample, but not their benchmark samples). The PD also mandated, for the first time, the enforcement of these required IPO prospectus disclosures.

These concurrent regulatory changes provide a potential alternative explanation for HHL's reported results. Additionally, the reported result $-\mathrm{a} 38-82 \%$ reduction in IPO underpricing — seems too large to be caused by mandatory IFRS adoption per se. If mandatory IFRS adoption caused a reduction in IPO underpricing of this magnitude, then it would have to be the case that, from a capital markets perspective, or at least in the IPO setting, domestic European GAAPs such as German GAAP and French GAAP are sub-optimal to an extraordinary degree. We 
know of no substantial published evidence that would suggest that this is the case. ${ }^{2,3}$ Anecdotal evidence also casts doubt on a causal relationship with mandatory IFRS adoption. Inconsistent with the existence of very large economic gains from IFRS adoption, after 2005 we find that the majority (78\%) of IPO firms admitted to trading on exchange-regulated markets that allow for a choice between IFRS and domestic GAAP choose to use domestic GAAP (see section 6). Finally, prior studies that examine the effect of mandatory IFRS adoption on all listed firms do not report average economic gains of this order of magnitude (e.g., see Byard, Li, and Yu 2011; or Daske, Hail, Leuz, and Verdi 2008, 2013). ${ }^{4}$ Notwithstanding these prior findings, we acknowledge that the IPO setting is unique: IPO firms do not have an extensive history of providing financial reports, so there is heightened uncertainty and information asymmetry. As a result, it is possible that mandating the use of a comprehensive and higher-quality set of accounting standards such as IFRS could provide for larger economic gains, on average, for IPO firms than for all listed firms.

Understanding whether HHL's results are causally related to IFRS adoption, or to one of the concurrent regulatory changes, in particular, PD adoption, is an important issue for policymakers (see Gow et al. 2016; Leuz and Wysocki 2016). While HHL's results suggest that mandatory IFRS adoption resulted in much larger economic gains for IPO firms than all listed firms, on average, this does not seem to be the belief of policymakers. As already discussed, concurrent with mandatory IFRS adoption, European policymakers made a number of regulatory

\footnotetext{
${ }^{2}$ Anglo-American/common law-based accounting standards, such as IFRS, are generally viewed as being more capital markets orientated than many domestic GAAPs. Indices of GAAP differences also confirm that IFRS are a more comprehensive set of standards than most domestic GAAPs (e.g., Bae, Tan, and Welker 2008). However, we know of no evidence which shows that, from a capital markets perspective, domestic GAAPs such as German or French GAAP are sub-optimal to such a degree that one could reasonably expect that mandating the use of IFRS rather than, say German GAAP, would cause a $38-82 \%$ reduction in IPO underpricing.

${ }^{3}$ Additionally, if the mechanism through which mandatory IFRS adoption reduces IPO underpricing is via increased disclosure quality, then it is unclear why, in the pre-2005 period: (1) IPO firms would not voluntarily adopt IFRS in countries where this is permitted (e.g., Germany), or (2) firms would not choose to provide additional voluntary disclosures when reporting in domestic GAAP. In the case of (1), prior to 2005 very few IPO firms voluntarily adopted IFRS.

${ }^{4}$ Similarly, the empirical financial accounting/capital markets literature has not documented extensive evidence that accounting disclosures cause economic effects of this order of magnitude. On the contrary, prominent studies report that accounting disclosures play a relatively small informational role in capital markets (Ball and Brown 1968; Ball and Shivakumar 2008).
} 
changes that allow IPO firms to avoid IFRS adoption (see section 2 for details). ${ }^{5}$ HHL's reported results showing very large economic gains to IPO firms from mandatory IFRS adoption suggest that this policy is in error. For these reasons, we believe that HHL's main reported result— that the 2005 mandatory adoption of IFRS is associated with a 38-82\% reduction in IPO underpricing-deserves re-examination.

When we began our analysis, we discovered that there is a large data error in HHL's treatment sample. HHL use listing status (whether a firm is publicly listed or traded) and country of domicile to identify their treatment sample of IPO firms subject to mandatory IFRS adoption. In doing so, they include all IPOs in the member states of the EU in the period 2006-2007 in their treatment sample of IPOs subject to mandatory IFRS adoption. As discussed already, this is incorrect: most IPOs on exchange-regulated markets in the member states of the EU after 2005 are not required to report in IFRS. We estimate that approximately 30\% of HHL's treatment sample in the period 2006-2007 is comprised of firms admitted to trading on exchange-regulated markets that are not subject to a mandate to report in IFRS. HHL mis-classified these IPO firms as mandatory IFRS adopters. Using hand-collected data from stock exchanges and IPO prospectuses, we verify that most of these firms went public using their domestic GAAPs, not IFRS (however, if they do use IFRS, this is a voluntary adoption). This large data error renders HHL's reported results unreliable.

While our purpose is not to replicate HHL's analysis, given the large data error in their study, we first check if their reported results are affected by their data error. Using the same data sources, we (1) assemble a correct treatment sample by removing the mis-classified IPOs, and (2) re-estimate, as closely as we can, HHL's main DID model. Using the same model and design as HHL, but the correct treatment sample, we find no statistically significant association between

\footnotetext{
${ }^{5}$ One possibility is that policymakers believe that smaller growth firms stand to benefit less from IFRS adoption than larger listed firms. Consistent with this belief, Fiechter, Halberkann, and Meyer (2018) show that, in Switzerland, firms that switch back from reporting in IFRS to using domestic GAAP tend to be smaller firms with higher inside ownership and less foreign investor holdings, suggesting that these firms benefit less from using IFRS. Switzerland is not a member of the EU or the European Economic Area (EEA); IFRS use is voluntary in Switzerland (see Zeff 2016).
} 
mandatory IFRS adoption and IPO underpricing. This indicates that HHL's reported results for IPO underpricing are materially affected by the significant data error in that study.

Using a sample of IPOs on EU-regulated markets, we also examine the joint effect of adoption of IFRS and the PD, together with increased accounting enforcement on both IFRS and PD adoption. Since both the IFRS and PD require increased disclosures, the effect of both directives is likely to be increased by the concurrent increase in accounting and disclosure enforcement in a number of countries during the sample period (Christensen et al. 2013). We can separately identify the effects of IFRS and PD adoption because the PD has staggered adoptionthe adoption date is different in each member state of the EU. We find that there is a statistically significant decrease in IPO underpricing associated with adoption of the PD in the five countries that increased accounting enforcement after they increased accounting enforcement. For firms in these countries, there is approximately a 23\% reduction in IPO underpricing during our sample period. However, we find no significant association between IPO underpricing and IFRS adoption.

As an alternative analysis of the possible economic gains to IPO firms arising from mandatory IFRS adoption, we also examine voluntary IFRS adoptions by firms admitted to trading on exchange-regulated markets after $2005 .{ }^{6}$ This provides for a novel setting to test for evidence of potential network effects/positive information externalities from IFRS adoption. Unlike a firm's voluntary IFRS adoption decision in the pre-2005 period, in the post-2005 period, a firm's adoption decision between using domestic GAAP and IFRS may be affected by the fact that IFRS is now widely used around the world and, hence, provides for a larger "reporting network," i.e., a larger number of industry peer firms reporting in the same accounting standards. ${ }^{7}$ At the margin, any potential economic gains from positive information externalities from access to a larger

\footnotetext{
${ }^{6}$ This analysis only applies to exchange-regulated markets that allowed firms to report in either domestic GAAP or IFRS. Three exchange-regulated markets did adopt IFRS as a listing requirement (see section 2 and Appendix for details); firms listed on these markets are required to adopt IFRS, so we treat them as mandatory IFRS adopters.

${ }^{7}$ Pierk (2018) also examines voluntary IFRS adoptions by firms admitted for trading on a sample of exchangeregulated markets after 2005. However, he does not examine the effect of the relative size of the IFRS reporting network on IPO firms' voluntary IFRS adoption decision.
} 
reporting network may make it more likely that an IPO firm admitted to trading on an exchangeregulated market would voluntarily adopt IFRS. We test this idea.

Using a sample of 419 IPOs on exchange-regulated markets in the period 2006-2007 that allowed a choice between domestic GAAP and IFRS, we find that 117 (about 28\%) of these IPOs choose to use IFRS. We also find that when a larger proportion of an IPO firm's domestic listed industry peers already report in IFRS, the IPO firm is (marginally significantly) more likely to choose to report in IFRS $(p<0.10$, two-tailed). This latter result is consistent with the presence of some positive externalities from network effects from using IFRS. Overall, however, these results do not suggest the presence of very large economic gains from network effects from enhanced comparability from reporting in IFRS rather than domestic GAAP.

In sum, we demonstrate that HHL's results showing that mandatory IFRS adoption is associated with a $38-82 \%$ reduction in IPO underpricing are unreliable as they are based upon the wrong treatment sample. Using the same research design and the correct treatment sample, we find no evidence that mandatory IFRS adoption is associated with a statistically significant (and economically large) decrease in IPO underpricing. For firms listing on EU-regulated markets, we find that adoption of the PD, together with enhanced accounting enforcement (Christensen et al. 2013), is associated with a decrease in IPO underpricing, but there is no effect from mandatory IFRS adoption. For firms admitted to trading on exchange-regulated markets after 2005, we find that (1) relatively few (28\%) of these firms voluntarily choose to use IFRS ( $78 \%$ choose to use domestic GAAP), and (2) these firms are only marginally more likely to choose to use IFRS when a larger fraction of the potential reporting network (\# industry peers reporting in the same accounting standards) already reports in IFRS. Overall, we find no evidence suggesting that mandatory IFRS adoption results in very large economic benefits to IPO firms.

Our study makes a number of other contributions. First, for the mandatory IFRS adoption literature, our results show that: (1) using country and listing status to identify EU firms subject to mandatory IFRS adoption in 2005 can result in a significant sampling error, and (2) in addition to increased accounting enforcement (Christensen et al. 2013), other concurrent EU regulatory 
changes bundled with mandatory IFRS adoption (e.g., adoption of the PD) are potentially important in explaining changes in some capital market outcomes. Second, our analysis highlights an important identification weakness in the DID model, as commonly used in international settings. In terms of providing causal evidence as to a treatment effect, the validity of the DID model rests upon the parallel trends assumption (e.g., see Imbens and Rubin 2015; Angrist, and Pischke 2009; Kahn-Lang and Lang 2019). Our analysis highlights that when treatment and benchmark firms are located in different countries, they are potentially exposed to different correlated regulatory shocks, which can invalidate the parallel counterfactual trends condition (Kahn-Lang and Lang 2019). ${ }^{8}$ Finally, our study provides an overview of important EU capital markets regulations relevant to accounting and finance scholars.

The remainder of this paper is organized as follows. Section 2 describes the institutional background, i.e., the major concurrent EU regulatory changes affecting the IPO setting. Section 3 reviews HHL's study design and sample selection and explains the source of the major data error in their study. Section 4 re-examines HHL's main result for IPO underpricing using the correct treatment sample. For a sample of IPOs on EU-regulated markets, Section 5 examines the joint effect of IFRS and PD adoption, together with increased accounting enforcement (Christensen et al. 2013), on IPO underpricing. Section 6 analyzes voluntary IFRS adoptions by firms admitted to trading on exchange-regulated markets after 2005. Section 7 presents our conclusions.

\section{Institutional Background: Relevant Concurrent Regulatory Changes}

Mandatory IFRS adoption in 2005 coincided with the implementation of a number of other new capital markets regulations in the member states of the EU, including adoption of the Prospectus Directive. This section provides a brief overview of the key concurrent regulatory changes that, a priori, may have affected IPO markets and IPO firms' reporting incentives.

\footnotetext{
${ }^{8}$ This possibility is hightened when either the treatment or benchmark samples are dominated by firms based in the member states of the EU; this is because, since the early 2000 s, these countries have coordinated the adoption of many new capital market regulations (see Christensen et al. 2013, 2016; Moloney 2014; Veil 2017).
} 


\subsection{EU-Regulated Markets vs. Exchange-Regulated Markets}

In 2004 the EU adopted Regulation (EC) No. 39/2004, the Markets in Financial Instruments Directive (hereafter "MiFID"). This directive defines a market for financial instruments and allows for an (EU) "regulated market" that is regulated by the "National Competent Authority" in the EU member state where the market is based; typically, this is the securities regulator in that country (e.g., Autorité des Marchés Financiers (AMF) in France, the Bundesanstalt für Finanzdienstleistungsaufsicht (BaFin) in Germany, and the Financial Conduct Authority (FCA) in the United Kingdom). EU regulated markets are automatically subject to all EU capital markets directives (see below), including the IFRS Directive. Stocks are said to be "listed" on such EU-regulated markets.

MiFID also allows for Multilateral Trading Facilities (MTFs) where securities can be traded in a relatively unregulated environment. After the adoption of the MiFID in 2004, many stock exchanges in the member states of the EU set up new MTFs. MTFs do not fall under the scope of a (EU) regulated market, so they are not subject to regulation by the designated National Competent Authority in the country where the market is based. These markets are not automatically subject to provisions of the major EU capital markets directives, such as the IFRS directive, and can decide for themselves whether or not to adopt provisions of key EU capital markets directives. ${ }^{9}$ These self-regulating secondary markets are known as "exchange-regulated" markets; firms are said to be "traded" on exchange-regulated markets.

There is an important distinction to be made between an exchange and a "market." As outlined above, EU capital markets law applies at the level of a market, not a stock exchange. Importantly, a stock exchange can contain multiple different (legal) markets. In a typical structure, a stock exchange in an EU member state will have a "main market" where larger firms are traded; this will be an EU-regulated market. This market is automatically subject to all EU capital markets

\footnotetext{
${ }^{9}$ This is true for the period 2006-2007, immediately after mandatory IFRS adoption, but it is not true for all aspects of EU capital markets law in later time periods. For example, in 2014 the EU replaced the Market Abuses Directive with the Market Abuses Regulation (see Moloney 2014); this new regulation applied to both EU-regulated markets and exchange-regulated markets.
} 
directives, including the IFRS Directive, and is regulated by the appropriate National Competent Authority in that country. Most firms listed on EU-regulated markets had to adopt IFRS from January $1,2005 .{ }^{10}$ Typically, within the same stock exchange, there will also be one or more secondary markets set up as MTFs. These are secondary markets where smaller firms are traded. Because a secondary market is set up as an MTF, it is not regulated by the National Competent Authority in that country; instead, it is regulated by the exchange- hence the term "exchangeregulated" market. Exchange-regulated markets are not subject to EU capital markets directives, including the IFRS Directive.

The minimum listing requirements for firms admitted to trading on exchange-regulated markets are also lower than for firms listed on EU-regulated markets (see CRA 2009; Brüggemann, Daske, Homburg, and Pope 2012; Gerakos, Lang, and Maffett 2013; Pierk 2014). For example, firms admitted to trading on exchange-regulated markets may not have to appoint independent board members, and may not have to apply other corporate governance rules that are mandatory for firms listed on the main EU-regulated market of the same stock exchange. The listing process can also be quite different: firms are frequently "admitted to trading" on exchange-regulated markets via placements rather than public offerings. Stocks can be placed with institutional investors and, after a lag of at least six months, can then be admitted to trading on an exchangeregulated market without a public offering. The exchange-regulated markets are designed to have a lower regulatory burden in order to encourage more new listings by smaller growth firms (see Vismara, Paleari, and Ritter 2012). As part of this lower regulatory burden, many exchange-

\footnotetext{
${ }^{10}$ Article 4 of Regulation (EC) No. 1606/2002, the IFRS Directive, states:

For each financial year starting on or after 1 January 2005, companies governed by the law of a Member State shall prepare their consolidated accounts in conformity with the international accounting standards adopted in accordance with the procedure laid down in Article 6(2) if, at their balance sheet date, their securities are admitted to trading on a regulated market of any Member State... (emphasis added).
}

The reference here to a "regulated market" refers to an EU-regulated market. This directive, therefore, does not automatically apply to MTFs, i.e., the exchange-regulated markets. Mandatory IFRS adoption applied to all firms listed on EU-regulated markets that report on a consolidated basis from January 1, 2005 (unless a firm is subject to a specific country-level exemption, see Pownall and Wieczynska 2018). 
regulated markets have not adopted the provisions of significant EU capital markets directives, including the IFRS Directive.

\subsection{Adoption of the Prospectus Directive (PD)}

In the early to mid-2000s, the EU implemented the Finacial Services Action Plan (FSAP), which was designed, among other things, to integrate capital markets across the member states of the EU into a single market for wholesale financial services (FSAP 1999). This plan led to the adoption of four significant EU capital markets directives: Market Abuse Directive (Regulation (EC) No 6/2003), the Transparency Directive (Regulation (EC) No 109/2004), the Prospectus Directive (Regulation (EC) No 71/2003; hereafter the "PD") in 2003, and the IFRS Directive in 2005. In many respects, the adoption of these four capital markets directives represented the development, for the first time, of a distinct EU capital markets law applicable in all of the member states of the EU (see Moloney 2014; Veil 2017). These four directives only apply to firms listed on EU-regulated markets. ${ }^{11}$

For IPO markets, the most significant of these directives was the adoption of the PD by the member states of the EU over the period 2005-2007 (with the adoption date varying by country). This directive requires the member states of the EU to adopt new rules mandating the minimum content of an IPO prospectus to be issued by firms going public on EU-regulated exchanges. The PD also mandates the enforcement of these minimum IPO prospectus disclosures. Specifically, the PD mandates that in each EU member state, the designated National Competent Authority must review and approve prospectuses for compliance with the PD and IFRS Directive. The PD was designed to both increase and harmonize public disclosures by IPO firms listing on EU-regulated markets across the member states of the EU (see Cleary Gottlieb Steen \& Hamilton 2004; Moloney 2014; Veil 2017). ${ }^{12}$ Prior studies show that increased prospectus disclosures are associated with

\footnotetext{
${ }^{11}$ Although not automatically subject to significant pieces of EU capital markets regulation, exchange-regulated markets may have their own tailored implementations of these regulations. For example, while the PD does not automatically apply to firms admitted to trading on exchange-regulated markets, firms that go public on an exchange-regulated market via a full public offering are likely to choose to provide a full prospectus in compliance with the PD, but this decision is voluntary (see ESME 2007).

12 To clarify, the PD sets out the procedures to be followed when drawing up and approving a prospectus. The required disclosures to be included in a prospectus, and the required format of a prospectus, are specified in the Prospectus
} 
decreased IPO underpricing (see Leone, Rock, and Willenborg 2007; Hanley and Hoberg 2010; Boone, Floros, and Johnson 2016), so it can be expected that adoption of the PD could decrease IPO underpricing for IPO firms listing on EU-regulated markets.

\subsection{The Status of IFRS on Exchange-Regulated Markets}

Adoption of the EU's four capital market directive in the mid-2000s dramatically increased regulation for firms listed on EU-regulated markets. Concurrent with this development, many stock exchanges in the EU set up new exchange-regulated markets. Since the new exchangeregulated markets were exempt from the provisions of these four newly adopted EU capital markets directives, they offered smaller IPO firms a way to avoid the heightened regulatory burden of listing on an EU-regulated market, including the requirement to report in IFRS.

As of June 2019, we have identified fifteen exchange-regulated markets that are part of fourteen different stock exchanges in Europe. See Appendix. ${ }^{13}$ Nine of these fifteen exchangeregulated markets were founded between 2005 and $2008 .{ }^{14}$ Only three exchange-regulated markets require IFRS: the Alternative Investment Market (AIM) in the United Kingdom, the Enterprise Securities Market (ESM) in Ireland, and the EN.A market in Greece. ${ }^{15}$ One exchange-regulated market, the First North market (part of Nasdaq Nordic), requires IFRS for the subset of firms traded

Regulation (Regulation (EC) No 809/2004), which deals with implementation of the PD (Veil 2017). Together, adoption of the PD and Prospectus Regulation had the potential to increase the required disclosures available for IPOs listing on EU-regulated markets. This is because, in the terminology of the EU, the PD is a "maximum harmonizing directive" (CRA 2009; Moloney 2014). That is the say, to achieve the objectives of harmonizing IPO regulations across the member states of the $\mathrm{EU}$, and to ensure investor protection, the approach taken in the PD is to converge IPO regulations in the member states of the EU towards a maximum. With adoption of the PD the required IPO disclosures for firms listing on EU-regulated markets, therefore, were both increased and harmonized across the member states of the EU (see Veil 2017).

${ }^{13}$ We include Norway in this list, even though Norway is not a member state of the EU. Norway is part of the European Economic Area (EEA) and, as such, adopts EU capital markets directives, including the IFRS directive. In addition to exchange-regulated markets that are MTFs that are part of stock exchanges, there are also independent MTFs, such as AktieTorget and Nordic MTF in Sweden; relatively few firms are traded in these independent MTFs, however.

${ }^{14}$ Specifically, the following exchange-regulated markets were founded in 2005 or shortly thereafter (see CRA 2009): Alternext (France, Netherlands, Belgium, and Portugal), the Entry Standard (Frankfurt, Germany), EuroMTF (Luxembourg), M.access (Munich, Germany), and the Enterprise Securities Market (Ireland), all founded in 2005; First North (Nordic), and EN.A (Greece), founded in 2006; the New Connect (Poland), founded in 2007; and the Mercado Alternativo Bursátil (Spain), founded in 2008.

${ }^{15}$ The AIM market requires all firms traded on that market to report in IFRS from 1/1/2007 (see London Stock Exchange 2006). The ESM and EN.A markets require IFRS since they were founded in 2005 and 2006, respectively. 
on the First North Premier segment of this market. The other eleven exchange-regulated markets do not require IFRS and continue to allow firms to report in domestic GAAP. ${ }^{16}$ Some firms traded in these markets do report in IFRS, but these are voluntary IFRS adopters (see Pierk 2018).

\section{Overview of HHL's Study Design and Sample Selection}

As already discussed, the primary motivation for this study is to test whether the very large reduction in IPO underpricing reported by HHL is due to mandatory IFRS adoption, or perhaps to the concurrent adoption of the PD in the member states of the EU (which are included in HHL's treatment sample). When we examined the IPO data, however, we discovered that there is a very large data error in HHL's treatment sample, which renders their reported results unreliable. Therefore, before examining the joint effect of IFRS and PD adoption, we first re-examine whether HHL's reported results for IPO underpricing hold using the correct treatment sample.

\subsection{Testing the Effect of Mandatory IFRS Adoption on IPO Underpricing}

HHL test the association between mandatory IFRS adoption and the change in IPO underpricing. IPO underpricing is the phenomenon whereby the offer prices of the newly issued shares of firms going public tend to be lower than their first trading-day closing prices. IPO underpricing has been attributed to information asymmetry among participants in the IPO process regarding the value of an IPO firm (Rock 1986; Beatty and Ritter 1986; Benveniste and Spindt 1989) and has been documented throughout the world (Loughran, Ritter, and Rydqvist 1994). Prior studies show that increased IPO disclosures are associated with a reduction in IPO underpricing (Leone et al. 2007; Hanley and Hoberg 2010; Boone et al. 2016). HHL argue that by increasing financial disclosures and comparability, mandatory IFRS adoption would reduce information asymmetry and, hence, a "firm's need to underprice an IPO" (HHL, p. 1381). They test this prediction using the following DID model:

$$
\text { Underpricing }=\beta_{0}+\beta_{1} \text { Post }+\beta_{2} \text { IFRS }+\beta_{3} \text { Post } \times I F R S+\text { Controls }+\varepsilon
$$

\footnotetext{
${ }^{16}$ For example, the listings requirements for Euronext Access state that firms admitted for trading on Euronext Access have "No obligation to publish accounts in IFRS format." See: https://www.euronext.com/en/listings/free-markets.
} 
The variable Post is an indicator variable coded zero (one) for the period 2003-2004 (20062007). The variable IFRS (which HHL label "Mandatory adopter") is an indicator variable coded one (zero) for IPO firms based in IFRS-adopting countries (non-IFRS-adopting countries), i.e., the treatment (benchmark) samples. To estimate Equation (1), HHL use a treatment sample of 1,540 IPOs domiciled in IFRS adopting countries over the sample period 2003-2004 (the pre-IFRS period) and 2006-2007 (the post-IFRS period). Their tests compare the change in IPO underpricing between the pre- and post-IFRS periods across this treatment sample and the following three benchmark samples: (1) a one-to-one propensity score (PS) matched benchmark sample of IPOs based in all non-IFRS adopting countries; (2) a one-to-one PS-matched benchmark sample of IPOs based in all non-IFRS adopting countries, except the U.S.; and (3) a benchmark sample of all IPOs in three developed countries, specifically, the U.S., Canada, and Japan. ${ }^{17}$ Equation (1) also includes Controls, a set of control variables for IPO characteristics (e.g., Offer size, Underwriter reputation), and industry fixed effects. The variable of interest is the interaction term Post $\times$ IFRS, which identifies the change in IPO underpricing between the pre- and post-mandatory IFRS adoption periods in the treatment sample relative to the benchmark sample.

Equation (1) provides for differences-in-differences (DID) tests. The parallel trends assumption is critical to the validity of interpreting the estimates from Equation (1) as providing causal evidence as to the effects of mandatory IFRS adoption on IPO underpricing (see Imbens and Rubin 2015; Angrist, and Pischke 2009). This is the assumption that, absent the mandatory IFRS adoption treatment, IPO underpricing would have continued to move in parallel across the treatment and benchmark samples. The change in IPO underpricing over the sample period in the benchmark sample is used to infer the (unobservable) potential outcome (the counterfactual) of what would have been the IPO underpricing in the treatment sample had the IFRS treatment not been applied. This assumes that, apart from mandatory IFRS adoption, there are no systematic shocks that differ across the treatment and benchmark samples during the treatment period.

\footnotetext{
${ }^{17}$ This third benchmark sample is not one-to-one PS matched with the treatment sample.
} 
However, as discussed in section 2, there are a number of significant regulatory and institutional shocks in the sample period that potentially affect IPO markets in the member states of the EU: these shocks only affect the treatment sample (since EU member states are all "IFRS adopting countries"). Because these shocks affect the treatment sample but not the benchmark samples, they invalidate the parallel trends assumption in this setting (see Kahn-Lang and Lang 2019). ${ }^{18}$ The results from estimates of Equation (1) cannot therefore be interpreted as providing causal evidence as to the effects of mandatory IFRS adoption.

\section{Examining the Association Between Mandatory IFRS Adoption and IPO Underpricing Using the Correct Treatment Sample}

HHL's treatment sample is composed of 469 IPOs from the pre-IFRS period (2003-2004) and 1,071 IPOs from the post-IFRS period (2006-2007). The 1,071 IPOs for the years 2006-2007 is the source of the data error: this part of HHL's treatment sample includes all IPOs on all stock markets in the EU in the years 2006-2007, including all IPOs on exchange-regulated markets. The data error is clear from the description of HHL's treatment sample contained in Table 1 of their paper. For example, in the case of France, HHL's Table 1 states that there are 124 French IPO firms in the period 2006-2007 in their treatment sample subject to mandatory IFRS adoption. Using the same data sources, we are able to identify 113 French IPOs in the same time period (see Table 1 of this paper). We check these IPOs using hand-collected data from stock exchanges and IPO prospectuses and find that 83 of these firms are admitted to trading on exchange-regulated markets that do not require IFRS (Alternext and Marché Libre). These firms are therefore not subject to a mandate to report in IFRS and should not be included in the treatment sample. ${ }^{19}$

\footnotetext{
${ }^{18}$ Establishing parallel trends in the pre-treatment period does not negate this criticism. Parallel trends in the pretreatment period are only suggestive of counterfactual parallel trends; establishing parallel trends in the pretreatment period is not sufficient to establish that the parallel counterfactual trends condition holds (Kahn-Lang and Lang 2019). A priori, the fact that we know that the treatment and benchmark sample are exposed to different concurrent shocks (adoption of the PD in the treatment sample) suggests that the parallel counterfactual trends condition does not hold here.

${ }^{19}$ We also checked the IPO prospectuses of these 83 firms and can confirm that all of them went public using French GAAP, not IFRS.
} 
As their primary data source, HHL use data from Security Data Company (SDC) Global New Issues database, which provides data on an IPO issuer, issue date, etc., and data from Datastream. For the period 2006-2007, using the same data sources, we identify 962 IPOs in the same "IFRS adopting countries." To correct the sampling error, we identify the listing market of these 962 IPOs and determine whether the firm was listed on an EU-regulated market or was admitted to trading on an exchange-regulated market. Data sources like Datastream and Global Compustat provide data on stock exchanges, but for this sample period, they do not provide data on the listing/trading market within a stock exchange. ${ }^{20}$ As a result, we hand-collect data on the listing market of these 962 IPO in the post-IFRS period.

\section{$<$ Insert Table 1 About Here >}

The country distribution of the 1,071 IPOs in HHL's treatment sample in the post-IFRS period is reproduced in Column (A) of our Table 1. For the same countries and sample period, we identify 962 IPOs when we follow, as best we can, HHL's sample selection procedure. The distribution of these 962 IPOs is presented in Column (B) of Table 1; this is our "Full Sample." To correct for the data error, we identify the listing/trading market of these 962 firms. To do so, we first designate a firm's country as the country where its main listing/trading market is based, not the firm's country of domicile (if they are different). ${ }^{21}$ For the Full Sample of 962 IPOs with available data, we hand-collect data from firms' IPO prospectus, listing stock exchange websites, and news articles, to identify which IPOs are listed on EU-regulated markets and which are admitted to trading on exchange-regulated markets. ${ }^{22}$ Among the 962 available IPOs, Column (C)

\footnotetext{
${ }^{20}$ Datastream does not provide data to identify a stock's listing market for this time period; this data is only available from 2012 onward (see Pownall and Wieczynska 2018).

${ }^{21}$ This results in the re-classification of a small number of IPOs. These are cases in which a firm is domiciled in one county, but its stock is only listed/trading on a stock exchange in another country. For example, Smartrac is a firm domiciled in the Netherlands that went public on the Frankfurt stock exchange in Germany in 2006.

${ }^{22}$ We use the following procedures to identify IPO firms' listing market. For European listing countries with both an EU-regulated market and an exchange-regulated market in this time period (i.e., Austria, Belgium, Denmark, Finland, France, Greece, German, Ireland, Italy, the Netherlands, Norway, Portugal, Sweden, and the United Kingdom), we use data from stock exchange websites and IPO prospectuses, or newswire services if not available from these two sources, to hand-collect listing market data for each IPO. For countries that did not have an exchangeregulated market in the period 2006-2007 (Spain, Australia, Hong Kong, the Philippines, and South Africa), we follow HHL and assume that all firms are main market listings that are subject to mandatory IFRS adoption.
} 
lists the "Excluded" firms: 314 firms that should not be included in the treatment sample because they were admitted to trading on exchange-regulated markets that do not require IFRS and 10 IPOs from Switzerland, which did not mandate IFRS adoption. ${ }^{23}$ Some of the 314 firms admitted to trading on exchange-regulated markets did use IFRS, but these are voluntary IFRS adoptions, and should not be included in the treatment sample. ${ }^{24}$

Recall, exchange-regulated markets can decide for themselves whether to require IFRS. The sponsoring stock exchange can adopt IFRS as a listing requirement for the market. As discussed in section 2, of the fifteen exchange-regulated markets, only three require IFRS: the Alternative Investment Market (AIM) in the United Kingdom, the Enterprise Securities Market (ESM) in Ireland, and the EN.A market in Greece. There are no firms admitted to trading on the ESM or EN.A markets in our Full Sample. The AIM market requires all firms to report in IFRS, effective 1/1/2007 (see London Stock Exchange 2006). There are quite a few firms that went public on the AIM market in 2007, and 2007 is included in HHL's post-IFRS adoption sample period. However, the IFRS Directive became effective on 1/1/2005 for firms listed on EU-regulated markets, and HHL exclude 2005 as this is a transition year. Excluding the transition year, 2005, is standard practice in the literature. Following the same logic, 2007 should be excluded for firms admitted to trading on AIM, as this is the transition year (to IFRS) for such firms. Hence, for consistency, we exclude IPOs on AIM in 2007, as well as 2006, from our corrected treatment sample. Column (D) of Table 1 shows the 638 IPO firms in the corrected treatment sample, which we label the "Correct Sample;" this is the Full Sample (Column (B)) less the Excluded firms (Column (C)). The exclusions result in a considerable change in the treatment sample for the postIFRS period: we drop just over a third $(33.68 \%, 324 / 962)$ of our Full Sample. This provides a

\footnotetext{
${ }^{23}$ Switzerland is not a member of either the EU or the European Economic Area (non-EU member countries such as Norway that follow EU regulations). EU capital markets directives such as the IFRS Directive therefore do not apply to Switzerland. Many Swiss listed firms have voluntarily adopted IFRS (Zeff 2016; IFRS Foundation 2017). Because the use of IFRS by listed firms in Switzerland is voluntary, there are cases where Swiss firms switch back from IFRS to domestic GAAP (see Fiechter et al. 2018).

${ }^{24}$ For firms admitted to trading on exchange-regulated markets, we use data from Thomson One to hand-check the IPO prospectus of each IPO firm to verify whether the firm went public using IFRS or domestic GAAP.
} 
rough estimate of the relative size of the data error in HHL's treatment sample for the post-IFRS period.

\section{$\underline{4.2 \text { Univariate Comparisons of Correct Sample, Excluded Firms, and Full Sample }}$}

Table 2 provides a univariate comparison of the firms we retain in our Correct Sample and the Excluded firms that we drop from the correct treatment sample. Column (A) shows data for Underpricing, Offer_Size, etc. for the 638 firms in our "Correct Sample," and Column (B) shows data for the 269 IPOs in this correct sample that are listed on EU-regulated markets. Data for the excluded firms are shown in Columns (C) and (D). Column (C) shows data for all 324 firms excluded firms; Column (D) shows data for the 314 of these firms that are admitted to trading on exchange-regulated markets (recall, the other ten excluded firms are IPOs from Switzerland).

\section{$<$ Insert Table 2 About Here >}

Columns (E) and (F) show the results of $t$-tests of comparisons across samples. Specifically, Column (E) shows the results of $t$-tests comparing Columns (A) and (C), i.e., comparing the 638 firms retained in the Correct Sample and the 324 firms excluded from the correct treatment sample. As can be seen in Table 2, fundamental characteristics of IPO firms such as Underpricing and Offer-Size are significantly different across these two groups of firms, indicating that HHL's data error fundamentally altered the types of IPO firms in their treatment sample in the post-IFRS period. Finally, Column (F) reports the results of similar $t$-tests comparing IPO fundamental characteristics across the 269 IPOs listed on EU-regulated markets (Column (B)) and the 314 IPOs admitted to trading on exchange-regulated markets (Column (D)). Consistent with prior studies (Vasmera et al. 2012), these results confirm that IPOs listed on EU-regulated markets are fundamentally different from those admitted to trading on exchange-regulated markets. For example, average underpricing is 0.060 for IPOs listed on EU-regulated markets, but 0.112 for IPOs admitted to trading on exchange-regulated markets; $t$-tests show that these are significantly different at $p<0.01$. This is consistent with the observation that IPOs on EU-regulated markets are subject to much more stringent regulatory requirements, including the PD, than those on exchange-regulated markets, resulting in lower underpricing. 
Finally, mean Underpricing is similar in Columns (C) and (D), but quite different in Columns (A) and (B), which leads to a significantly positive (negative) value in Column (E) (Column (F)). The difference between Columns (A) and (B) is mainly due to Australian IPOs; the Full Sample shown in Column (A) includes Australian IPOs, which have higher underpricing, on average, than IPOs on EU-regulated markets.

\section{$\underline{4.3 \text { Estimating Equation (1) Using the Correct Treatment Sample }}$}

To examine whether HHL's results still hold using the correct treatment sample, we reestimate Equation (1) using our Full Sample and the Correct Sample as the treatment sample for the post-IFRS adoption period. Our treatment sample for the pre-IFRS period is very similar to that used by HHL: we identify 462 IPOs in "IFRS adopting countries" in the period 2003-2004, which is only seven observations less than that used in HHL. As far as we can tell, our benchmark samples are also quite close to those used in HHL. ${ }^{25}$ For both our Full Sample and Correct Sample, we follow, as best we can, the same sample selection procedures as HHL to select the one-to-one PS-matched benchmark samples that we match with either our Full Sample or our Correct Sample. As our Full and Correct samples differ somewhat from that of HHL, it follows that our PS-matched benchmark samples also differ somewhat. The results are shown in Table 3. For this analysis, we follow, as best we can, the procedures set out in HHL. That is, we report results for estimates of Equation (1), using the same three benchmark samples used by HHL. ${ }^{26}$

$$
<\text { Insert Table } 3 \text { About Here }>
$$

Columns (A) to (C) of Table 3 show the results of our re-estimate of Equation (1) using our Full Sample. For these estimates, we obtain results that are very similar to those reported in

\footnotetext{
${ }^{25}$ Specifically, Table 4 of HHL reports that for the test using the $3^{\text {rd }}$ non-PS matched benchmark sample, they use a sample with 2,901 firm observations. Since their treatment sample has 1,540 observations, this implies that their $3^{\text {rd }}$ benchmark sample has 1,361 observations. Our $3^{\text {rd }}$ benchmark sample is very similar (1,290 observations). As Table 3 shows our tests using our $3^{\text {rd }}$ benchmark sample use a sample of 2,714 firm observations, of which 1,424 firm observations are from our treatment sample, and 1,290 are from our benchmark sample.

${ }^{26}$ The three benchmark sample are: (1) a one-to-one PS- matched benchmark sample of IPOs based in all non-IFRS adopting countries; (2) a one-to-one PS-matched benchmark sample of IPOs based in all non-IFRS adopting countries, except the U.S.; and (3) a benchmark sample of all IPOs in three developed countries - the U.S., Canada, and Japan. This third benchmark sample is not one-to-one PS matched with the treatment sample. For (1) and (2) we first re-estimate HHL's propensity scores as best we can, and rematch our Full and Correct treatment samples with the benchmark samples.
} 
Table 4 of HHL. Specifically, HHL report that the coefficient on Post $\times I F R S$ (see Post $\times$ Mandatory Adopter in Table 4 of HHL) is significantly negative at $p<0.05$, two-tailed, for two of the three benchmark samples, and at $p<0.10$, two-tailed, in the third benchmark sample. The results of our re-estimate of Equation (1) using our Full Sample (which does not correct for the data error) are quite similar: the coefficient on Post $\times I F R S$ is significantly negative at $p<0.05$, two-tailed, for one of the three benchmark samples, and at $p<0.10$, two-tailed, for the other two of the benchmark samples. While these results are not intended as an exact replication of HHL, they are quite close. This indicates that any differences in our sample selection and PS matching from that used by HHL are not material as they do not fundamentally alter the overall tenure of the results.

Columns (D) to (F) of Table 3 show the results of our re-estimate of Equation (1) using our Correct Sample. Here we find that while the coefficient on Post $\times$ IFRS is negative for all three benchmark samples, none are statistically significant at conventional levels. That is to say, using the same model and benchmark samples as HHL, but using the correct treatment sample, we find no evidence that mandatory IFRS adoption is associated with a statistically significant decrease in IPO underpricing. Overall, our results reported in Table 3 indicate that HHL's reported results showing that mandatory IFRS adoption is associated with a statistically significant decrease in IPO underpricing are incorrect and seem to be attributable, in part, to the use of the wrong treatment sample.

\subsection{Interpreting Results from Equation (1) as Causal Evidence}

It should be noted that even if the results from re-estimating Equation (1) using the correct treatment sample showed a statistically significant negative coefficient on Post $\times I F R S$, this could not be interpreted as providing causal evidence as to the effects of mandatory IFRS adoption. As discussed in section 2, mandatory IFRS adoption coincided with significant regulatory changes in the EU that likely affected the IPO market —in particular the adoption of the PD. Adoption of the PD affected IPOs on EU-regulated markets, which are included in the corrected treatment sample. The corrected treatment sample is therefore exposed to a significant concurrent shock that does not affect the benchmark samples. PD adoption is therefore a correlated omitted variable (as it is 
correlated with IFRS, the treatment variable, in Equation (1)). In terms of the DID design, since the treatment sample is exposed to concurrent regulatory shocks that do not affect the benchmark samples (which are comprised of firms from "non-IFRS adopting countries"), the parallel trends assumption, critical to drawing causal inferences from the DID design, is violated (see Kahn-Lang and Lang 2019). ${ }^{27}$

\section{Examining the Joint Effect of IFRS and PD Adoption}

\section{$\underline{5.1 \text { IPOs on EU-Regulated Markets: The Joint Effect of IFRS and PD Adoption }}$}

Both the IFRS Directive and the PD only apply to IPOs listing on EU-regulated markets. To provide evidence as to the relative importance of these two concurrently-enacted EU capital markets directives that may have affected IPO underpricing, we use a sample of IPO firms listed on EU-regulated markets to test the joint effect of IFRS and PD adoption on IPO underpricing. The IFRS Directive applied to most firms (see Pownall and Wieczynska 2018) listing on EUregulated markets from 1/1/2005 onward (the adoption date is the same in all EU member states). The PD was adopted by the EU in 2003 and, like many new EU regulations, had to be separately enacted into national law in each EU member state — via each country's own national legislative processes. As a result, the provisions of the PD came into effect on different dates in different EU member states, i.e., there is staggered adoption. ${ }^{28}$ The adoption dates varied from $3 / 15 / 2005$ for Spain to 3/29/2007 for Italy. We exploit this staggered adoption to provide for separate identification of the effects of IFRS and PD adoption. Variation in the timing of adoption of the

\footnotetext{
${ }^{27}$ Since the treatment firms and benchmark firms are located in different countries, differences in macroeconomic shocks across "IFRS-adopting countries" and "non-IFRS-adopting countries" during the treatment period could also potentially invalidate the parallel trends condition in this setting. It is noteworthy in this regard that HHL report very big differences in the magnitude of the treatment effect identified when the country composition of the benchmark sample changes. Specifically, HHL report that mandatory IFRS adoption is associated with a $38 \%$ reduction in IPO underpricing when the benchmark sample is a one-to-one PS-matched sample of IPOs based in all non-IFRS adopting countries, but an $82 \%$ reduction in IPO underpricing when the benchmark sample is a oneto-one PS-matched sample of IPOs based in all non-IFRS adopting countries, except the U.S. That is to say, dropping the U.S. from the benchmark sample changes the magnitude of the average identified effect of IFRS adoption from a $38 \%$ to an $82 \%$ decrease in IPO underpricing.

${ }^{28}$ This is also the case for adoption of the Transparency and Market Abuse Directives (see Christensen, Hail, and Leuz 2016). In contrast, the IFRS Directive had a common effective date that applied to all EU member states.
} 
PD is likely due to differences in national legislative processes across the different member states of the EU, which are effectively exogenous to the IPO market.

We select a sample of IPOs on EU-regulated markets between one year before the first adoption of the PD (in Spain) and one year after the last adoption of the PD (in Italy), i.e., between 3/15/04 and 3/28/08. This provides for a sample of 280 IPOs on EU-regulated markets: see Panel A of Table 4. For each IPO subject to the treatment (i.e., those offered in the post-PD period or those reporting in IFRS), we search for a counter-factual observation without treatment (i.e., those offered in the pre-PD period or those using domestic GAAP), matching by country and industry. This provides for a sample balanced between pre-and post-PD periods, and between IFRS- and domestic GAAP-reporting IPOs within a country-industry pair: see Panel B of Table 4.

$<$ Insert Table 4 About Here $>$

Concurrent with IFRS and PD adoption, the EU also required EU member states to increase the enforcement of accounting standards (Christensen et al. 2013). Specifically, each EU member state was required to designate a National Competent Authority (typically a securities regulator) mandated to review the financial statements of firms listed on EU-regulated markets for compliance with IFRS. The PD also mandated that a National Competent Authority be responsible for reviewing prospectuses for compliance with the disclosure requirements of the PD. These changes in accounting and disclosure enforcement overlap with the adoption of the IFRS Directive and the PD in five countries (Finland, Germany, the Netherlands, Norway, and the United Kingdom); other EU member states increased accounting enforcement later. Christensen et al. (2013) show that changes in liquidity around mandatory IFRS adoption for listed firms are largely due to the concurrent increases in accounting enforcement in these five countries. It is similarly feasible that the concurrent increase in accounting enforcement may have strengthened and reinforced the effect of IFRS and PD adoption for IPO firms in these five countries. We therefore test whether the impact of IFRS and PD adoption on IPO underpricing is stronger for IPOs based in these five countries, after the increase in accounting enforcement in these five countries. 
Using our sample of 280 IPOs on EU-regulated markets, we test the joint effect of IFRS and PD adoption, together with increased accounting and disclosure enforcement, using the following model:

$$
\begin{aligned}
& \text { Underpricing }=\alpha_{0}+\alpha_{1} I F R S+\alpha_{2} I F R S \times E n f+\alpha_{3} P D+\alpha_{4} P D \times E n f \\
& \quad+\text { Controls }+ \text { Country } \times \text { Industry Fixed Effects }+ \text { Year Fixed Effects }+\varepsilon,
\end{aligned}
$$

where IFRS is an indicator variable coded one (zero) if an IPO reports in IFRS (domestic GAAP) according to WorldScope. $P D$ is an indicator variable coded one (zero) for IPOs after (before) the PD came into force in the country where the IPO firm lists. Because the PD had a different adoption date in each EU-member state, IFRS and $P D$ are not collinear. Enf is an indicator variable coded one (zero) for an IPO in one of the five countries that increased accounting and disclosure enforcement in our sample period, after the date of the increase in enforcement in that country, and zero otherwise. On its own, we expect no effect from increased accounting enforcement. However, the IFRS and PD directives both require that IPO firms provide increased disclosures. We expect that increased accounting enforcement could, therefore, strengthen the effect of either the IFRS or PD directive. We include the interaction terms IFRS $\times E n f$ and $P D \times E n f$ in Equation (2) to identify any incremental impact (on IPO underpricing) of IFRS and PD adoption when they are coupled with increased accounting and disclosure enforcement. The sequence of events in our data is such that the increase in accounting enforcement (Enf) always follows IFRS and PD adoption in all affected countries: there are observations for which increased accounting enforcement $(E n f=1)$ is coupled with PD adoption $(P D=1)$ but not IFRS adoption $(I F R S=0)$ and visa versa, but there are no instances for which accounting enforcement has increased $(E n f=1)$ before the IFRS or PD directive has been adopted.

\section{$<$ Insert Table 5 About Here >}

The results from estimating Equation (2) are shown in Table 5. We find no evidence that IFRS is statistically significantly associated with a change in IPO underpricing. For the PD, the only statistically significant coefficients are for the interaction term $P D \times E n f$. In the full model that includes both IFRS, PD, and the two interaction terms IFRS $\times E n f$ and $P D \times E n f$, we find that 
$P D \times E n f$ is significantly negative at $p<0.05$, two-tailed. These results suggest that for IPOs on EUregulated markets, adoption of the $\mathrm{PD}$, coupled with increased accounting and disclosure enforcement, is associated with a statistically significant decrease in IPO underpricing; however, there is no evidence that mandatory IFRS adoption is associated with a decrease in IPO underpricing. It is important to keep in mind that there are three events here-adoption of IFRS, adoption of the $\mathrm{PD}$, and an increase in accounting and disclosure enforcement (Enf) in five of the sample countries - and that they are not randomly distributed. IFRS adoption precedes PD adoption, which precedes the increase in accounting and disclosure enforcement. For firms based in the five countries that increased accounting enforcement during the sample period (Finland, Germany, the Netherlands, Norway, and the UK), the regression coefficiently translates into approximately a $23 \%$ reduction in IPO underpricing following all three regulatory changes. The statistically significant coefficient on $P D \times E n f$ indicates that the PD, when coupled with increased accounting enforcement, is the key development (in terms of reducing IPO underpricing). Caution is warranted, however, in interpreting this result as reflecting the effects of $P D$ and Enf adoption per se. This is because of the possibility of selection effects associated with PD adoption and increased accounting enforcement (Enf); specifically, the possibility that, after adoption of the PD and increased accounting enforcement for firms listed on EU-regulated markets, lower-quality firms may have chosen to be admitted to trading on exchange-regulated markets rather than seek a full listing on an EU-regulated market.

Unlike Equation (1), for our estimates of Equation (2), we do not use a benchmark/control sample of IPOs based in non-IFRS adopting countries. As discussed in Section 4, given the range of concurrent regulatory changes in the EU affecting IPO firms, we do not believe that using a control sample of IPO firms based in non-IFRS adopting countries will provide for enhanced identification in this setting. Instead, we recognize the fact that firms listing on EU-regulated markets are distinctly different from other IPOs, in that they are affected by both IFRS and PD adoption, and we restrict ourselves to using a sample of only IPOs listed on EU-regulated markets. Further, we exploit the staggered adoption of the PD to identify the separate effects of IFRS and 
PD adoption. Our estimates of Equation (2) identify the impact of IFRS and PD adoption by comparing an IPO on an EU-regulated market after one (or both) of these new regulations come into effect, with another IPO also on an EU-regulated market, but prior to when these two regulations came into effect, while controlling for IPO firm characteristics and country and industry effects.

There are two limitations to this analysis. First, after 2005, smaller and lower-quality firms may choose to be admitted to trading on exchange-regulated markets rather than list on EUregulated markets. This may increase the average quality of firms that list on EU-regulated markets in the post-IFRS and PD adoption periods relative to the pre-IFRS and PD adoption periods. We include controls for firm characteristics, but if firms differ along unobservable dimensions, this would likely introduce a bias towards finding an effect for either IFRS or PD adoption. However, we see no reason why, if present, such a bias would be endogenous to adoption of the PD (and only in a subset of five countries), but not IFRS adoption.

Second, IPO markets and underpricing may be affected by market sentiment, which can change over time (e.g., see Ljungqvist, Nanda, and Singh 2006). This is important since, like many regulatory change studies, we identify the effects of both IFRS and PD adoption using time-based variables (i.e., indicator variables that change over time as the new regulations become effective). Our identification in Equation (2) rests upon the staggered adoption of the PD in different countries. We see no reason however to suspect that market sentiment would be endogenous to one regulation adoption, and not to the other. Further, we see no reason to believe that any timevarying sentiment/shocks would be endogenous to a subset of countries that also concurrently increased their accounting enforcement.

\subsection{What About the Impact of Mandatory IFRS Adoption in Non-EU Member States?}

Our results suggest that among IPO firms based in the member states of the EU that were subject to mandatory IFRS adoption in 2005, i.e., firms that listed on EU-regulated markets, mandatory IFRS adoption had no effect on IPO underpricing. Of course, there is also a considerable proportion of firms based in non-EU member states, especially Australia, that were 
subject to mandatory IFRS adoption in 2005, and which are also part of HHL's treatment sample. For completeness, we also re-ran Equation (1) using the sub-sample of treatment sample firms based in non-EU member states (Australia, Hong Kong, the Philippines, and South Africa), again using the same three benchmark samples. The untabulated results show that Post $\times$ IFRS is insignificant in all three estimates of Equation (1).

\section{$\underline{5.3 \text { Other Concurrent Regulatory Changes and IPO Firms' Relative Foreign Proceeds }}$}

In addition to examining the association between mandatory IFRS adoption and IPO underpricing, HHL also use the same DID framework to examine the association between mandatory IFRS adoption and IPOs firms" "relative foreign proceeds" (the proportion of proceeds raised in foreign markets; RFPs hereafter). HHL report that mandatory IFRS adoption is associated with a 49-76\% increase in IPO firms' RFPs (see HHL, p. 1367). We do not replicate these tests as the primary purpose of this study is not to replicate the entirety of HHL's study. Rather, the primary purpose of this study is to re-examine whether HHL's reported results claiming to show that mandatory IFRS adoption is associated with a $38-82 \%$ decrease in IPO underpricing are, in fact, due to the concurrent adoption of the PD. In any event, like IPO underpricing, HHL's results for relative foreign proceeds are based upon the same incorrect treatment sample, so the reported results are unreliable. ${ }^{29}$

\footnotetext{
${ }^{29}$ Providing causal evidence as to what drives any change in IPO's relative foreign proceeds over this time period would also be extremely challenging. This is because mandatory IFRS adoption in the EU was part of the EU's Financial Services Action Plan (FSAP), a package of over forty regulatory changes intended to integrate the capital markets of the member states of the EU into a single capital market (see FSAP 1999; Christensen et al. 2013). A key objective of the FSAP was to remove "the outstanding barriers to raising capital on an EU-wide basis," and the plan included numerous regulatory changes that were intended to make it easier for a firm based in one EU member state to raise capital from investors in other EU member states. Mandatory IFRS adoption therefore overlaps with numerous other regulatory changes to integrate EU capital markets. Examples include: (1) the 2005 adoption of the "Cross-Border Merger and Acquisitions Directive," to remove regulatory and legal barriers impeding cross-border M\&As between firms based in different member states of the EU (Regulation (EC) No. 56/2005), and (2) adoption of the "passporting provisions" of the PD that allow an IPO firm to use a prospectus approved by a regulatory authority in one EU member state to issue securities on any EU-regulated market in any other EU member states (CRA 2009; Moloney 2014; Veil 2017). The latter provision of the PD was intended to make it easier for IPOs to raise capital from investors located in other member states of the EU (see Cleary et al. 2004; ESME 2007; ESMA 2016).
} 


\section{Evidence from Firms' Voluntary IFRS Adoption Decisions and Policymakers' Actions}

There are limitations to using temporal changes in market outcomes like IPO underpricing to measure the potential benefits of mandatory IFRS adoption for IPO firms. This is because market outcomes like IPO underpricing can be affected by market sentiment, which can change over time (Ljungqvist et al. 2006). To mitigate concerns arising from this inherent limitation of IPO underpricing, as an alternative we also examine the potential impact of mandatory IFRS adoption on IPO firms by examining an observable firm choice variable. Specifically, for firms admitted to trading on exchange-regulated markets, we examine IPO firms' voluntary adoptions of IFRS because such a choice is not as directly linked to market sentiment as market outcomes such as IPO underpricing.

\subsection{IPO Firms' Voluntary IFRS Adoption Decisions After 2005}

Because IPO firms do not have a long history of reporting, there is heightened uncertainty. As a result, the disclosures of other similar firms (e.g., industry peers reporting in the same accounting standards) may play a more important role in decreasing investors' uncertainty (see Shroff, Verdi, and Yost 2017). Any positive information externalities arising from mandatory IFRS adoption may therefore be more critical in the IPO setting than for already-listed firms; IPO firms may therefore provide a powerful setting to test for the effect of any positive information externalities from network effects associated with mandatory IFRS adoption.

Recall, IPO firms admitted to trading on most exchange-regulated markets after 2005 could choose between using IFRS and domestic GAAP. This provides for a novel setting to test for evidence of the existence of positive information externalities/network effects arising from enhanced comparability from using IFRS. In the post-2005 period, there is now a large number of listed industry peers reporting in IFRS. As a result, when choosing between using domestic GAAP and IFRS, a firm being admitted to trading on an exchange-regulated market after 2005 may consider the fact that IFRS is now widely used around the world and, hence, provides for a larger "reporting network," i.e., a larger network of industry peers reporting in the same accounting standards. This larger reporting network may reduce investors' uncertainty and, hence, the firm's 
cost of capital. If the larger reporting network under IFRS provides for very big economic gains to IPO firms (from enhanced comparability in a larger network), then, at the margin, we would expect that IPO firms would be more likely to choose to use IFRS when it provides for a larger reporting network than domestic GAAP.

With this in mind, we exploit the voluntary IFRS adoption decisions of IPO firms admitted to trading on exchange-regulated markets in the post-2005 period to test whether access to a larger reporting network under IFRS affects these firms' decision to use IFRS or domestic GAAP. Specifically, using a sample of IPOs from exchange-regulated markets for 2006-2007, we estimate the following probit model:

$$
\begin{aligned}
\operatorname{Prob}(\text { Vol_IFRS }=1)_{-} & \varphi_{1}+\varphi_{2} \text { IFRSNetworkSize }+\varphi_{3} \text { Offer_Size }+\varphi_{4} \text { Cross } \\
& + \text { Country fixed effects }+ \text { Year fixed effects }+\varepsilon,
\end{aligned}
$$

where Vol_IFRS is an indicator variable coded one (zero) if a firm chooses to report in IFRS (domestic GAAP). We include controls for Offer_Size, which is the offer value divided by the average offer size of all IPOs in the country, and Cross, which is an indicator variable coded one if an IPO is listing outside of its home country, and zero otherwise. Equation (3) also includes sets of country and year fixed effects.

The variable of interest in Equation (3) is IFRSNetworkSize, which is a proxy for the proportion of an IPO firm's potential reporting network that is using IFRS. We use two different measures of IFRSNetworkSize: (1) the proportion of an IPO firm's domestic industry peers reporting in IFRS: (1+\#IFRS-reporting domestic industry peers)/(1+\#all domestic industry peers); and (2) the proportion of an IPO firm's global industry peers reporting in IFRS: (1+\#IFRSreporting global industry peers $) /(1+\#$ all global industry peers $)$. When a greater proportion of an IPO firm's listed industry peers are already reporting in IFRS, we expect this will provide for greater potential benefits from enhanced comparability under IFRS (rather than domestic GAAP). We expect that higher values of IFRSNetworkSize will therefore be associated with a greater incentive for an IPO firm to choose to report in IFRS rather than domestic GAAP; hence we test the prediction that $\varphi_{2}>0$. 
$<$ Insert Table 6 About Here >

For the period 2006-2007, we identify a sample of 419 IPO firms admitted to trading on exchange-regulated markets that allowed for a choice between domestic GAAP and IFRS in countries where we observe at least one IPO firm each using IFRS or domestic GAAP. Of these 419 IPO firms, 117 firms (about 28\%) choose to use IFRS (see Panel B of Table 6). Panel B of Table 6 shows the country distribution of the 302 (117) firms that choose to use domestic GAAP (IFRS). The results from estimating Equation (3) using our two measures of IFRSNetworkSize are shown in Panel $\mathrm{C}$ of Table 6. The results show that when IFRSNetworkSize is measured as the proportion of global industry peers that report in IFRS, it is not associated with an IPO firm's decision to report in IFRS rather than domestic GAAP. However, when IFRSNetworkSize is measured as the proportion of an IPO firm's domestic industry peers that report in IFRS, it is marginally significantly positively associated with an increased likelihood that an IPO firm chooses to report in IFRS rather than domestic GAAP $(p<0.10$, two-tailed). The coefficient of 1.343 indicates that an IPO firm is approximately 34\% more likely to choose to report in IFRS (rather than domestic GAAP) when all of its domestic listed industry peers already report in IFRS.

To summarize, the results in Table 6 show that (1) the majority of firms (about $72 \%$ ) admitted to trading on exchange-regulated markets that allowed a choice between domestic GAAP and IFRS in the period 2006-2007 choose to use domestic GAAP, and (2) the proportion of an IPO firm's domestic listed industry that already reports in IFRS is marginally significantly positively ( $\mathrm{p}<0.10$ level, two-tailed) associated with the IPO firm's propensity to choose to report in IFRS. Taken together, these results suggest that while the use of IFRS may provide IPO firms with some economic benefits from network effects arising from enhanced comparability, IPO firms traded on exchange-regulated markets do not behave as if they believe that these economic benefits are very large.

\subsection{Additional Evidence from Observing Policymakers' Choices}

Evidence from the actions taken and beliefs held by policymakers (Gow et al. 2016) can also shed light on the plausibility of the claim that mandatory IFRS adoption resulted in a $38-82 \%$ 
reduction in IPO underpricing. In particular, we note that concurrent with mandatory IFRS adoption, EU policymakers put in place new regulations that allowed for the setting up of new exchange-regulated markets that did not have to comply with the IFRS Directive. Further, policymakers at most European stock exchanges chose not to require IFRS as a listing requirement for the new exchange-regulated markets that were founded in 2005 or shortly thereafter, and that were designed to encourage more new listings by smaller growth firms. These actions by European policymakers are inconsistent with the belief that mandatory IFRS adoption would result in very significant economic gains for IPO firms; rather, the actions of policymakers at European stock exchanges are consistent with the belief that smaller growth IPO firms would stand to benefit less from IFRS adoption than other listed firms. ${ }^{30}$

\section{Conclusions}

We re-examine the claim by Hong, Hung, and Lobo (the Accounting Review 2014; HHL) that mandatory IFRS adoption is associated with very large economic benefits for IPO firms, specifically a $38-82 \%$ reduction in IPO underpricing. Importantly, HHL overlooked a number of significant concurrent regulatory changes, such as the adoption of the EU's Prospectus Directive that are likely relevant to the IPO setting. From a policymaking perspective, it is important to know whether any very large decrease in IPO underpricing was causally related to IFRS adoption or was, in fact, due to the concurrent adoption of the PD (Gow et al. 2016; Leuz and Wysocki 2016).

When we re-examine HHL's results, we find that there is a very significant data error in their treatment sample that renders their reported results unreliable. We estimate that approximately $30 \%$ of HHL's treatment sample of IPO firms subject to mandatory IFRS adoption is comprised of IPO firms that are not subject to a mandate to report in IFRS. These are firms admitted to trading on exchange-regulated markets in the EU after 2005. We hand-collected data from IPO firms' prospectuses, we confirm that most of these firms went public using domestic

\footnotetext{
${ }^{30}$ This belief is supported by the evidence that, in Switzerland, firms that switch back from reporting in IFRS to using domestic GAAP tend to be smaller firms with higher inside ownership and less foreign investor holdings (see Fiecher et al. 2018).
} 
GAAP, not IFRS. Using the same design but with the correct treatment sample, we find no evidence that mandatory IFRS adoption is associated with a significant decrease in IPO underpricing.

Using a sample of IPOs on EU-regulated markets we examine the joint effect of IFRS and PD adoption, together with the concurrent increased accounting enforcement in five European countries (Christensen et al. 2013). We find that, for IPOs on EU-regulated markets, there is a significant decrease in IPO underpricing associated with the adoption of the PD when it is coupled with increased accounting enforcement; further, the decrease in IPO underpricing is about $23 \%$. Again, however, for this sample of IPOs on EU-regulated markets, we find no evidence of an association between mandatory IFRS adoption and IPO underpricing.

In theory, mandatory IFRS adoption could result in economic benefits to listed firms, including IPO firms, via two potential mechanisms. First, as a more comprehensive set of accounting standards than most domestic GAAPs (see Bae et al. 2008), mandatory IFRS adoption could potentially result in higher levels of disclosure and/or improved reporting quality. If mandatory IFRS adoption significantly increased reporting quality for IPO firms, then one would expect that the effect should be stronger in countries that concurrently increased accounting and disclosure enforcement. However, in our analysis of IPOs on EU regulated markets, we find no evidence that this is the case.

The second mechanism whereby mandatory IFRS adoption could result in large economic benefits for IPO firms is from potential positive information externalities/network effects from a larger reporting network in IFRS. As an international set of accounting standards, IFRS can obviously provide for a much larger reporting network, i.e., a larger number of industry peer firms reporting in the same accounting standards, than domestic GAAP. This could result in positive information externalities/network effects arising from increased comparability (Cascino and Gassen 2015; Gao, Jiang, and Zhang 2019). We examine voluntary IFRS adoptions by IPO firms admitted to trading on exchange-regulated markets after 2005 for evidence consistent with the existence of such network benefits from using IFRS. While we find some marginally statistically 
significant evidence consistent with the presence of some gains from network effects from using IFRS, our results are not consistent with the belief that any such economic gains from network effects are very large. Specifically, inconsistent with the existence of very large economic gains from network effects from using IFRS, we find that the majority $(72 \%)$ of IPO firms choose to report in domestic GAAP, not IFRS. ${ }^{31}$ As we already discussed, the fact that policymakers exempt firms on exchange-regulated markets from mandatory IFRS adoption also strongly suggests a limited benefit for IPO firms.

Our study makes a number of other contributions. First, for the broader mandatory IFRS adoption literature, we show that using country and listing status to identify a treatment sample of firms subject to mandatory IFRS adoption can result in a material sampling error. We show that this data error can materially affect reported results, at least in the IPO setting. Second, we show that concurrent regulatory changes adopted as part of the EU's Financial Services Action Plan that were bundled with mandatory IFRS adoption (e.g., the PD) are potentially important in explaining changes in some capital market outcome over this time period. Our analysis also highlights a potential weakness of the differences-in-differences (DID) design when used in international settings. Specifically, our analysis highlights that when treatment and benchmark firms are located in different countries, they are potentially exposed to different correlated shocks, invalidating the parallel trends assumption. Finally, our study also provides an overview of important EU capital markets regulations potentially relevant to accounting and finance scholars (see also Moloney 2014; Veil 2017).

${ }^{31}$ The alternative explanation is that the once-off direct costs of converting from domestic GAAP to IFRS are so large as to outweigh any recurring economic gains from network effects from using IFRS so that the majority of IPO firms choose to use domestic GAAP. 


\section{References}

Angrist, J., and J. Pischke. 2009. Mostly harmless econometrics: An empiricist's companion. Princeton University Press.

Bae, K., H. Tan, and M. Welker. 2008. International GAAP differences: the impact on foreign analysts. The Accounting Review 83 (3): 593-628.

Baker, M., J. Wurgler, and Y. Yuan. 2012. Global, local, and contagious sentiment. Journal of Financial Economics 104 (): 272-287.

Ball, R., 2006. International Financial Reporting Standards (IFRS): pros and cons for investors. Accounting and Business Research 36: 5-27.

Ball, R., and P. Brown. 1968. An empirical evaluation of accounting income numbers. Journal of Accounting Research 6(2): 159-178

Ball, R., A. Robin, and J. Wu. 2003. Incentives versus standards: Properties of accounting income in four East Asian countries. Journal of Accounting and Economics 36: 235-270.

Ball, R., and L. Shivakumar. 2005. Earnings quality in U.K. private firms. Journal of Accounting and Economics 39: 83-128.

Ball, R., and L. Shivakumar. 2008. How much new information is there in earnings? Journal of Accounting Research 46(5): 975-1016.

Beatty, R., and J. Ritter. 1986. Investment banking, reputation, and the underpricing of initial public offerings. Journal of Financial Economics 15: 213-232.

Benveniste, L., and P. Spindt. 1989. How investment bankers determine the offer price and allocation of new issues. Journal of Financial Economics 24: 343-362.

Boone, A., I. Floros, and S. Johnson. 2016. Redacting proprietary information at the initial public offering. Journal of Financial Economics 120: 102-123.

Brüggemann, U., H. Daske, C. Homburg, and P. Pope. 2012. How do individual investors react to global IFRS adoption? Working paper, Humboldt University. Available at:

http://papers.ssrn.com/sol3/papers.cfm?abstract_id=1458944\&download=yes

Brüggemann, U., J.-M Hitz, and T. Sellhorn. 2013. Intended and unintended consequences of mandatory IFRS adoption: A review of extant evidence and suggestions for future research. European Accounting Review 22: 1-37.

Burgstahler, D., L. Hail, and C. Leuz. 2006. The importance of reporting incentives: Earnings management in European private and public firms. The Accounting Review 81: 983-1017. 
Bushee, B., and C. Leuz. 2005. Economic consequences of SEC disclosure regulation: Evidence from the OTC bulletin board. Journal of Accounting and Economics 39: 233-264.

Byard, D., Y. Li, and Y. Yu. 2011. The effect of mandatory IFRS adoption on financial analysts' information environment. Journal of Accounting Research 49: 69-96.

Cascino, S., and J. Gassen. 2015. What drives the comparability effect of mandatory IFRS adoption? Review of Accounting Studies 20: 242-282.

Christensen, H., L. Hail, and C. Leuz. 2013. Mandatory IFRS reporting and changes in enforcement. Journal of Accounting and Economics 56: 147-177.

Christensen, H., L. Hail, and C. Leuz. 2016. Capital-market effects of securities regulation: Prior conditions, implementation, and enforcement. Review of Financial Studies 29: 2885-2924.

Cleary, Gottlieb, Steen \& Hamilton. 2004. The prospectus directive: Creating a single European passport. Available at: https://www.clearygottlieb.com/ //media/cgsh/files/publicationpdfs/the-prospectus-directive---creating-a-single-european-passport.pdf

CRA. 2009. Evaluation of the economic impacts of the Financial Services Action Plan, Final report prepared for the European Commission, CRA International, London.

Daske, H., L. Hail, C. Leuz, and R. Verdi. 2008. Mandatory IFRS reporting around the world: Early evidence on the economic consequences. Journal of Accounting Research 46: 10851142.

Daske, H., L. Hail, C. Leuz, and R. Verdi. 2013. Adopting a label: Heterogeneity in the economic consequences around IAS/IFRS adoptions. Journal of Accounting Research 51 (3): 495547.

De George, E., X. Li, and L. Shivakumar. 2016. A review of the IFRS adoption literature. Review of Accounting Studies 21: 898-1004.

European Securities Markets Expert Group (ESME). 2007. Report on Directive 2003/71/EC of the European Parliament and of the Council on the prospectus to be published when securities are offered to the public or admitted to trading. Available at: http://ec.europa.eu/internal_market/securities/docs/esme/05092007_report_en.pdf

European Securities and Markets Authority (ESMA). 2016. Report EEA prospectus activity in 2015. Available at: https://www.esma.europa.eu/document/report-eea-prospectus-activityin-2015

Fiechter, P., J. Halberkann, and C. Meyer. 2018. Determinants and consequences of a voluntary turn away from IFRS to local GAAP: Evidence from Switzerland. European Accounting Review 27(5): 955-989. 
FSAP. 1999. Implementing the framework for financial markets: action plan. See: https://eurlex.europa.eu/legal-content/EN/TXT/?uri=LEGISSUM\%3A124210

Gao, P., X. Jiang, G. Zhang. 2019. Firm value and market liquidity around the adoption of common accounting standards. Journal of Accounting and Economics, Forthcoming.

Gerakos, J., M. Lang, and M. Maffett. 2013. Post-listing performance and private sector regulation: The experience of London's Alternative Investment Market. Journal of Accounting and Economics 56: 189-215.

Gow, I., D. Larcker, and P. Reiss. 2016. Causal inferences in accounting research. Journal of Accounting Research 54(2): 477-523.

Hanley, K., and G. Hoberg. 2010. The information content of IPO prospectuses. Review of Financial Studies 23: 2821-2864.

Hong, H., M. Hung, and G. Lobo. 2014. The impact of mandatory IFRS adoption on IPOs in global capital markets. The Accounting Review 89: 1365-1397.

ICAEW (2015). The effects of mandatory IFRS adoption in the EU: A review of empirical research. In Information for better markets. Institute of Chartered Accountants in England and Wales. Available at: https://www.icaew.com/en/archive/technical/financialreporting/information-for-better-markets/ifbm-reports/the-effects-of-mandatory-ifrsadoption-in-the-eu

IFRS Foundation. 2017. Jurisdiction profiles. Available at: http://www.ifrs.org/use-around-theworld/use-of-ifrs-standards-by-jurisdiction/

Imbens, G. and D. Rubin. 2015. Causal inference for statistics, social, and biomedical sciences. Cambridge University Press.

Kahn-Lang, A., and K. Lang. 2019. The promise and pitfalls of differences-in-differences: Reflections on 16 and pregnant and other applications. Journal of Business \& Economic Statistics, Forthcoming.

Leone, A., S. Rock, and M. Willenborg. 2007. Disclosure of intended use of proceeds and underpricing in initial public offerings. Journal of Accounting Research 45: 111-153.

Leuz, C. 2003. IAS versus US GAAP: Information asymmetry-based evidence from Germany's new market. Journal of Accounting Research 41: 445-72.

Leuz, C., D. Nanda, and P. Wysocki. 2003. Earnings management and investor protection: An international comparison. Journal of Financial Economics 69: 505-527.

Leuz, C., and R. Verrecchia. 2000. The economic consequences of increased disclosure. Journal of Accounting Research 38: 91-124. 
Leuz, C., and P. Wysocki. 2016. The economics of disclosure and financial reporting regulation: Evidence and suggestions for future research. Journal of Accounting Research 54 (2): 525621.

Ljungqvist, A., V. Nanda, and R. Singh. 2006. Hot markets, investor sentiment, and IPO pricing. The Journal of Business 79 (4): 1667-1702.

London Stock Exchange. 2006. AIM rules - Update on AIM notice 15 and confirmation of permissible accounting standards. Available at: http://www.londonstockexchange.com/companies-and-advisors/aim/advisers/aimnotices/aim-notice-22.pdf

Loughran, T., J. Ritter, and K. Rydqvist. 1994. Initial public offerings: International insights. Pacific-Basin Finance Journal 2: 165-199.

Moloney, N. 2014. EU Securities and Financial Markets Regulation, $3^{\text {rd }}$ Edition. Oxford University Press, Oxford (UK).

Pierk, J. 2014. Three essays on determinants of accounting choice. Ph.D. Dissertation, Humboldt University. Available at: http://edoc.hu-berlin.de/dissertationen/pierk-jochen-2014-1024/PDF/pierk.pdf

Pierk, J., 2018. IPOs and IFRS in European exchange-regulated markets: A research note. Journal of Accounting and Public Policy 37: 477-485.

Pownall, G., and M. Wieczynska. 2018. Deviations from the mandatory adoption of IFRS in the European Union: Implementation, enforcement, incentives, and compliance. Contemporary Accounting Research 35(2): 1029-1066.

PricewaterhouseCoopers (PwC). 2008. Which market? A guide to selecting an equity listing market across Europe. Available at: https://www.pwc.ru/en/capital-markets/assets/whichmarket-eng.pdf

PricewaterhouseCoopers (PwC). 2012. IFRS adoption by country. Available at: http://www.pwc.com/us/en/issues/ifrs-reporting/publications/ifrs-status-country.jhtml

Regulation (EC) No 1606/2002 of the European Parliament and of the Council of 19 July 2002 on the Application of International Accounting Standards. Available at: http://eurlex.europa.eu/LexUriServ/LexUriServ.do?uri=CONSLEG:2002R1606:20080410:EN:PD $\underline{F}$

Regulation (EC) No 6/2003 of the European Parliament and of the Council of 28 January 2003 on insider trading and market manipulation (market abuse). Available at: http://eurlex.europa.eu/legal-content/EN/ALL/?uri=CELEX\%3A32003L0006 
Regulation (EC) No 71/2003 of the European Parliament and of the Council of 4 November 2003 on the prospectus to be published when securities are offered to the public or admitted to trading. Available at: http://eurlex.europa.eu/LexUriServ/LexUriServ.do?uri=OJ:L:2003:345:0064:0089:EN:PDF

Regulation (EC) No 39/2004 of the European Parliament and of the Council of 21 April 2004 on markets in financial instruments. Available at: http://eur-lex.europa.eu/legalcontent/EN/TXT/?uri=celex\%3A32004L0039

Regulation (EC) No 109/2004 of the European Parliament and of the Council of 15 Dec 2004 on the harmonisation of transparency requirements in relation to information about issuers whose securities are admitted to trading on a regulated market. Available at: http://eurlex.europa.eu/LexUriServ/LexUriServ.do?uri=OJ:L:2004:390:0038:0057:EN:PDF

Regulation (EC) No 809/2004 of the European Commission of 29 April 2004 implementing Directive 2003/71/EC of the European Parliament and of the Council as regards information contained in prospectuses as well as the format, incorporation by reference and publication of such prospectuses and dissemination of advertisements. Available at: http://ec.europa.eu/internal_market/securities/docs/prospectus/reg-2004-809/reg-2004$\underline{809 \text { en.pdf }}$

Regulation (EC) No 56/2005 of the European Parliament and of the Council of 26 October 2006 on cross-border mergers of limited liability companies. Available at: https://eurlex.europa.eu/legal-content/EN/TXT/?uri=CELEX\%3A02005L0056-20140702

Rock, K., 1986. Why new issues are underpriced. Journal of Financial Economics 15: 187-212.

Shroff, N., R. Verdi, and B. Yost. 2017. When does peer-firm information matter? Journal of Accounting and Economics 64 (2-3): 187-214.

Veil, R. (ed.). 2017. European Capital Markets Law, $2^{\text {nd }}$ Edition. Hart Publishing, Oxford (UK).

Vismara, S., S. Paleari, and J. Ritter. 2012. Europe's second markets for small companies. European Financial Management 18: 352-388.

Zeff, S. 2016. "In the literature" but wrong: Switzerland and the adoption of IFRS. Journal of Accounting and Public Policy 35: 1-2. 


\section{Appendix: Markets for Trading Stocks Within European Stock Exchanges (as of 2017) and the Status of}

IFRS Within Each Market

\begin{tabular}{|c|c|c|c|c|}
\hline $\begin{array}{l}\text { Exchange } \\
\text { (1) }\end{array}$ & $\begin{array}{c}\text { Countries } \\
(2)\end{array}$ & $\begin{array}{c}\text { Markets } \\
\text { Within Exchange } \\
\text { (3) }\end{array}$ & $\begin{array}{l}\text { Legal Status of } \\
\text { Market } \\
\text { (4) }\end{array}$ & $\begin{array}{r}\text { Does the IF } \\
\text { Directive App } \\
\text { this Mark } \\
\text { (as of 2017 } \\
\text { (5) }\end{array}$ \\
\hline $\begin{array}{l}\text { Athens Stock } \\
\text { Exchange }\end{array}$ & Greece & $\begin{array}{l}\text { Main Market } \\
\text { EN.A }\end{array}$ & $\begin{array}{l}\text { EU-Regulated } \\
\text { Exchange-Regulated }\end{array}$ & $\begin{array}{l}\text { Yes, from } 2005 \\
\text { Yes }\end{array}$ \\
\hline Borsa Italiana & Italy & $\begin{array}{l}\text { MTA } \\
\text { AIM Italia }\end{array}$ & $\begin{array}{l}\text { EU-Regulated } \\
\text { Exchange-Regulated }\end{array}$ & $\begin{array}{l}\text { Yes, from } 2005 \\
\text { No }\end{array}$ \\
\hline Euronext & $\begin{array}{l}\text { Belgium } \\
\text { France } \\
\text { Netherlands } \\
\text { Portugal }\end{array}$ & $\begin{array}{l}\text { Euronext Main Market } \\
\text { Euronext Grown } \\
\quad \text { (formerly Alternext) } \\
\text { Euronext Access } \\
\quad \text { (formerly Marché Libre) }\end{array}$ & $\begin{array}{l}\text { EU-Regulated } \\
\text { Exchange-Regulated } \\
\text { Exchange-Regulated }\end{array}$ & $\begin{array}{l}\text { Yes, from } 2005 \\
\text { No } \\
\text { No }\end{array}$ \\
\hline $\begin{array}{l}\text { Frankfurt Stock } \\
\text { Exchange }\end{array}$ & Germany & $\begin{array}{l}\text { The Regulated Market } \\
\text { Primary Standard \& } \\
\text { General Standard } \\
\text { The Entry Standard } \\
\text { (part of the "Open } \\
\text { Market") }\end{array}$ & Exchange-Regulated & Yes, from 2005 \\
\hline $\begin{array}{l}\text { Irish Stock } \\
\text { Exchange }\end{array}$ & Ireland & $\begin{array}{l}\text { Main Securities Market } \\
\text { Enterprise Securities Market }\end{array}$ & $\begin{array}{l}\text { EU-Regulated } \\
\text { Exchange-Regulated }\end{array}$ & $\begin{array}{l}\text { Yes, from } 2005 \\
\text { Yes, from } 2007\end{array}$ \\
\hline $\begin{array}{l}\text { London Stock } \\
\text { Exchange }\end{array}$ & $\begin{array}{l}\text { United } \\
\text { Kingdom }\end{array}$ & $\begin{array}{l}\text { Main Market } \\
\text { Alternative Investment } \\
\text { Market (AIM) }\end{array}$ & $\begin{array}{l}\text { EU-Regulated } \\
\text { Exchange-Regulated }\end{array}$ & $\begin{array}{l}\text { Yes, from } 2005 \\
\text { Yes, from } 2007\end{array}$ \\
\hline $\begin{array}{l}\text { Luxembourg } \\
\text { Stock Exchange }\end{array}$ & Luxembourg & $\begin{array}{l}\text { Bourse de Luxembourg } \\
\text { Euro MTF }\end{array}$ & $\begin{array}{l}\text { EU-Regulated } \\
\text { Exchange-Regulated }\end{array}$ & $\begin{array}{l}\text { Yes, from } 2005 \\
\text { No }\end{array}$ \\
\hline $\begin{array}{l}\text { Munich Stock } \\
\text { Exchange }\end{array}$ & Germany & $\begin{array}{l}\text { Main Market } \\
\text { M.access }\end{array}$ & $\begin{array}{l}\text { EU-Regulated } \\
\text { Exchange-Regulated }\end{array}$ & $\begin{array}{l}\text { Yes, from } 2005 \\
\text { No }\end{array}$ \\
\hline $\begin{array}{l}\text { NEX } \\
\text { Exchange }\end{array}$ & $\begin{array}{l}\text { United } \\
\text { Kingdom }\end{array}$ & $\begin{array}{l}\text { NEX Exchange } \\
\text { NEX Exchange Growth } \\
\text { Market }\end{array}$ & $\begin{array}{l}\text { EU-Regulated } \\
\text { Exchange-Regulated }\end{array}$ & $\begin{array}{l}\text { Yes, from } 2005 \\
\text { No }\end{array}$ \\
\hline $\begin{array}{l}\text { Nasdaq } \\
\text { Nordic }\end{array}$ & $\begin{array}{l}\text { Denmark } \\
\text { Finland } \\
\text { Iceland } \\
\text { Norway } \\
\text { Sweden }\end{array}$ & $\begin{array}{l}\text { Main Market } \\
\text { First North } \\
\text { First North Premium* }\end{array}$ & $\begin{array}{l}\text { EU-Regulated } \\
\text { Exchange-Regulated } \\
\text { Exchange-Regulated }\end{array}$ & $\begin{array}{l}\text { Yes, from } 2005 \\
\text { No } \\
\text { Yes, from } 2009\end{array}$ \\
\hline Oslo Børs & Norway & $\begin{array}{l}\text { Oslo Børs - Main Market } \\
\text { Oslo Axess } \\
\text { Merkur Market }\end{array}$ & $\begin{array}{l}\text { EU-Regulated } \\
\text { EU-Regulated } \\
\text { Exchange-Regulated }\end{array}$ & $\begin{array}{l}\text { Yes, from } 2005 \\
\text { Yes, from } 2005 \\
\text { No }\end{array}$ \\
\hline Spanish Stock & Spain & Main Market & EU-Regulated & Yes, from 2005 \\
\hline
\end{tabular}




\begin{tabular}{|c|c|c|c|c|}
\hline Exchange & & $\begin{array}{l}\text { Mercado Alternativo Bursátil } \\
(\mathrm{MaB})\end{array}$ & Exchange-Regulated & No \\
\hline $\begin{array}{l}\text { Vienna Stock } \\
\text { Exchange }\end{array}$ & Austria & $\begin{array}{l}\text { Official Market } \\
\text { Second Regulated Market } \\
\text { Third Market }\end{array}$ & $\begin{array}{l}\text { EU-Regulated } \\
\text { EU-Regulated } \\
\text { Exchange-Regulated }\end{array}$ & $\begin{array}{l}\text { Yes, from } 2005 \\
\text { Yes, from } 2005 \\
\text { No }\end{array}$ \\
\hline $\begin{array}{l}\text { Warsaw Stock } \\
\text { Exchange }\end{array}$ & Poland & $\begin{array}{l}\text { Main Market } \\
\text { New Connect }\end{array}$ & $\begin{array}{l}\text { EU-Regulated } \\
\text { Exchange-Regulated }\end{array}$ & $\begin{array}{l}\text { Yes, from } 2005 \\
\text { No }\end{array}$ \\
\hline
\end{tabular}

This table lists the main stock exchanges in Europe and the separate legal markets for trading stocks within each stock exchange, as of 2017. Note, these exchanges can also contain other specialist markets for trading debt securities. Column (1) lists the exchange, Column (2) lists the county where the exchange is based, Column (3) lists the different legal markets for stocks within each exchange, Column (4) shows whether each distinct legal market is an EU-regulated market or an exchange-regulated market, and Column (5) lists whether firms listed or traded in each market are required to report in IFRS, as of August 2017. The term "market" here refers to a distinct legal market, as defined in EU Regulation (EC) No. 39/2004, the Markets in Financial Instruments Directive ("MiFID"). As can be seen above, European stock exchanges are typically structured with multiple distinct legal markets: a main market that is an EU-regulated market, and therefore subject to all EU regulations, and an exchange-regulated market that can decide whether or not to adopt key EU directives, including the IFRS Directive. Larger international stocks typically trade on the main (EU-regulated) market, while smaller stocks trade on the exchange-regulated market (Vismara et al. 2012).

Exchange-regulated markets are set up as Multilateral Trading Facilities (MTFs) as defined by the MiFID. As such, they do not fall under the scope of a "regulated market," so they are not subject to regulation by the Competent National Authority in each EU member states (usually this is the securities regulator, such as Autorité des Marchés Financiers (AMF) in France), and are not automatically subject to EU directives like the IFRS Directive. The sponsoring stock exchange can decide whether to adopt provisions of EU directives such as the IFRS Directive, the Transparency Directive, the Market Abuses Directive, or the Prospectus Directive for this market. In addition to this different regulatory structure, the minimum listing requirements, governance standards, and listing process are also different for exchange-regulated markets. Firms are said to be "listed" on an EU-regulated market, but "admitted to trading" on an exchange-regulated market, since the latter markets merely provide a trading venue for stocks. Many firms are admitted to trading on exchange-regulated markets via placements rather than public offerings. Table 1 lists the exchange-regulated markets that are MTFs within a stock exchange. There are also independent MTFs that provide a trading venue for stocks; examples are Nordic MTF and AktieTorget in Sweden. These independent MTFs are equivalent to the exchange-regulated markets, but relatively few firms are traded in these venues.

* First North Premium is a segment within the First North market. The First North market is an MTF and does not require IFRS. However, IFRS is required for admission to the First North Premium segment within this market which was set up in 2009. 
Table 1: Identifying the Correct Post-2005 Treatment Sample

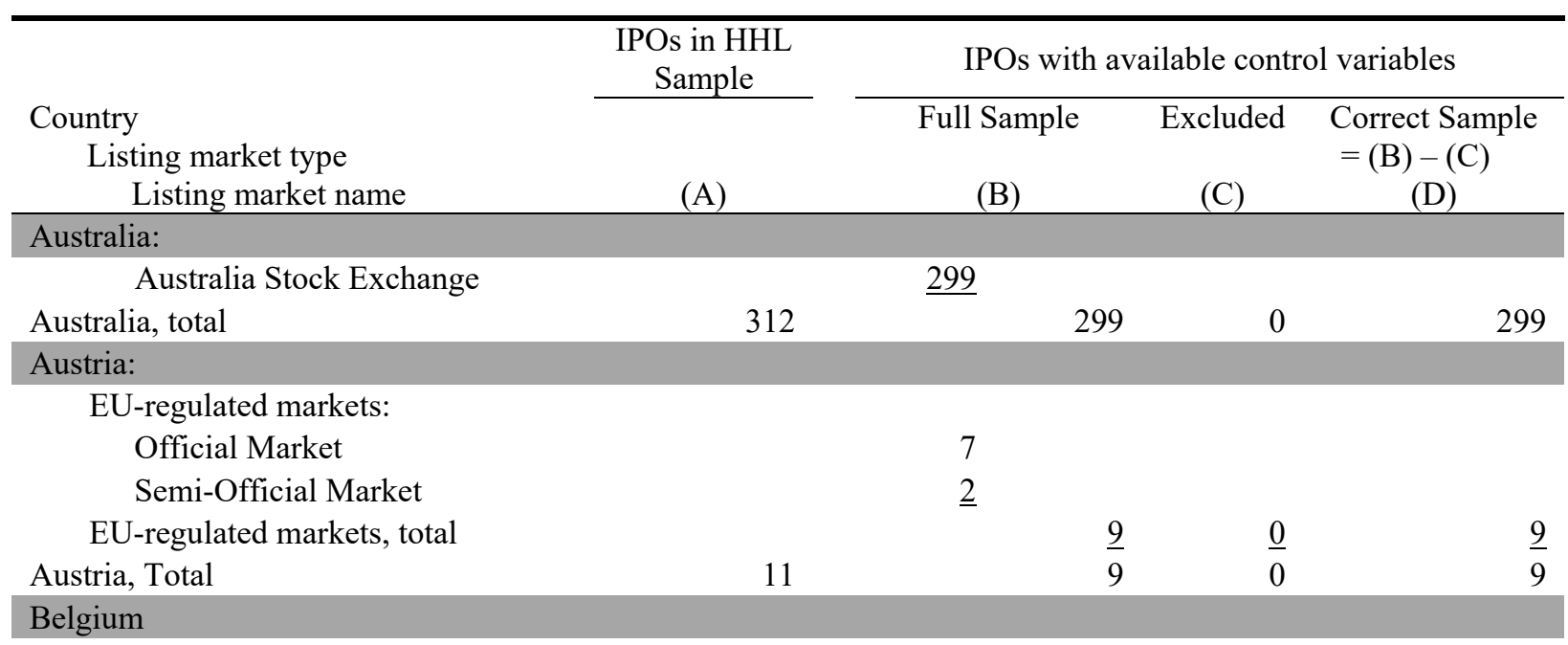

EU-regulated markets:

Euronext Brussels

EU-regulated markets, total

$\underline{11}$

Exchange-regulated markets:

Alternext Brussels

Marché Libre Brussels

Exchange-regulated markets, total

Belgium, total

Denmark

EU-regulated markets:

Copenhagen Stock Exchange

$\underline{12}$

Denmark, EU-regulated markets

Denmark, Total

14

$11 \quad 0$

11

\section{Finland}

EU-regulated markets:

Helsinki Stock Exchange

EU-regulated markets, total

Exchange-regulated markets:

FirstNorth: Helsinki

Exchange-regulated markets, total

Finland, total

6

$\underline{4}$

$\frac{10}{21} \quad \frac{10}{10}$

$\underline{\mathbf{0}}$

11

France

EU-regulated markets:

Euronext Paris

EU-regulated markets, total

$\underline{30}$

Exchange-regulated markets:

Alternext Paris

Marché Libre: Paris

\section{$\underline{5}$}

$5 \quad 0$

Exchange-regulated markets, total

$\underline{23}$

France, Total

124

$\underline{1}$

1

$\underline{12}$

$\underline{12}$

$12-0$

12

Germany

EU-regulated markets: 
Prime Standard

General Standard

5

Hamburg Regular Market

EU-regulated markets, total

1

Exchange-regulated markets:

Entry Standard

48

48

Open Market

23

Exchange-regulated markets, total

$\underline{5}$

Germany, Total

78

$\frac{28}{76} \quad \frac{28}{28}$

$\underline{\mathbf{0}}$

Greece

EU-regulated markets:

Athens Stock Exchange

EU-regulated markets, total

Greece, Total

Hong Kong

\section{Hong Kong Stock Exchange \\ Hong Kong GEM}

Hong Kong, Total

Ireland

EU-regulated markets:

Irish Stock Exchange

EU-regulated markets, total

Ireland, Total

Italy

EU-regulated markets:

Telematico Azionario

Mercato Expandi

30

EU-regulated markets, total

Italy, Total

53

$\underline{5}$

$\begin{array}{lll}\frac{5}{5} & \underline{0} & \underline{5}\end{array}$

57

1

$\begin{array}{lll}78 & 58 & 0\end{array}$

58

Netherlands

EU-regulated markets:

Euronext Amsterdam

EU-regulated markets, total

Exchange-regulated markets:

Alternext Amsterdam

Exchange-regulated markets, total

Netherlands, Total

16

1

15

$\begin{array}{lll}\underline{1} & \underline{0} & \frac{1}{1}\end{array}$

$\underline{18}$

$\begin{array}{llll}\underline{48} & \underline{0} & \underline{48}\end{array}$

Norway

EU-regulated markets:

Oslo Børs

19

Oslo Axess

$\underline{5}$

$5 \quad 0 \quad 5$

EU-regulated markets, total

Norway, Total

Philippines

Philippines Stock Exchange

Philippines, total

$\underline{1}$

1

Poland

EU-regulated markets:

Warsaw Stock Exchange

EU-regulated markets, total

$\underline{1}$

$\underline{11}$

11

$\begin{array}{lll}\frac{1}{6} & \underline{1} & \underline{0}\end{array}$

$\underline{8}$

$\begin{array}{llll}26 & \frac{27}{27} & 0 & 27\end{array}$

$11 \underline{0}$

11 
Poland, Total

0

1

Portugal

EU-regulated markets:

Euronext Lisbon

EU-regulated markets, total

Portugal, Total

South Africa

Johannesburg Stock Exchange

South Africa, total

$\underline{2} \quad \underline{0} \quad \underline{2}$

20

2

Spain

EU-regulated markets:

Madrid Stock Exchange

Barcelona Stock Exchange

EU-regulated markets, total

Spain, Total

1

$\begin{array}{lll}6 & 1 & 0\end{array}$

1

Sweden

EU-regulated markets:

OMX: Stockholm

EU-regulated markets, total

10

Exchange-regulated markets:

AktieTorget*

FirstNorth: Stockholm

Exchange-regulated markets, total

Sweden, total

Switzerland

Swiss Stock Exchange**

Switzerland, Total

15

1

$\begin{array}{llll}\frac{16}{16} & \underline{0} & \underline{16}\end{array}$

UK

EU-regulated markets:

Main Market

International Main Market

EU-regulated markets, total

Exchange-regulated markets:

AIM

PLUS*

Exchange-regulated markets, total

22

$\underline{12}$

12

$\underline{\mathbf{0}}$

11

$\begin{array}{rrrr}\frac{12}{22} & \underline{12} & \underline{0} \\ & 12 & 10\end{array}$

$\underline{10}$

$16 \underline{10} \quad 10$

10

10

0

32

?

$39 \quad 0$

39

UK, total

Total

1,071

177

$\underline{2}$

\begin{tabular}{|c|c|c|c|}
\hline & 179 & 179 & $\underline{\mathbf{0}}$ \\
\hline 220 & 218 & 179 & 39 \\
\hline 1,071 & 962 & 324 & 638 \\
\hline
\end{tabular}

This table summarizes the treatment sample for the post-IFRS adoption period, i.e., 2006-2007. Column (A) reproduces the country distribution of the 1,071 firms in HHL's treatment sample from the 2006-2007 period (this is from HHL's Table 1). Column (B) shows the country distribution of the 962 IPO firms we identify in the same IFRSadopting countries when we reproduce, as best we can, HHL's sample selection criteria using the same data sources. Among these 962 IPOs with available data, Column (C) lists the country distribution of the firms that identify that should be excluded from the treatment sample because they are not subject to a mandate to report in IFRS; these are firms that are mis-classified in HHL's treatment sample as mandatory IFRS adopters. Column (D) shows the country distribution of the correct treatment sample for the post-IFRS adoption period (Column (B) - Column (C)).

* The AktieTorget market in Sweden and the PLUS market in the United Kingdom are independent MTFs. These are markets with the same legal status as an exchange-regulated market; firms admitted to trading on this market were not subject to mandatory IFRS adoption. 
** Switzerland is not a member state of the EU or part of the European Economic Area (EAA). Firms listed on Swiss Stock Exchanges are permitted, but not required, to use IFRS (see Zeff 2016; IFRS Foundation 2017).

*** While AIM is an exchange-regulated market, it mandates the adoption of IFRS for financial reports of accounting periods beginning from January 1, 2007. 
Table 2: Comparison of Correct Post-2005 Treatment Sample and Firms Dropped from the Full Sample

\begin{tabular}{|c|c|c|c|c|c|c|c|c|}
\hline \multirow[b]{3}{*}{ Underpricing } & \multicolumn{2}{|c|}{$\begin{array}{c}\text { IPOs Included in Correct } \\
\text { Sample }\end{array}$} & \multicolumn{2}{|c|}{$\begin{array}{l}\text { IPOs Excluded from Full } \\
\text { Sample }\end{array}$} & \multicolumn{4}{|c|}{ Difference Between Subsamples } \\
\hline & \multirow{2}{*}{$\begin{array}{c}\text { All IPOs } \\
\text { Included } \\
(\mathrm{A})\end{array}$} & \multirow[t]{2}{*}{$\begin{array}{l}\text { IPOs on } \\
\text { EU-reg. } \\
\text { markets } \\
(\mathrm{B}) \\
0.060\end{array}$} & \multirow{2}{*}{$\begin{array}{c}\begin{array}{c}\text { IPOs } \\
\text { excluded } \\
(\mathrm{C})\end{array} \\
0.112\end{array}$} & \multirow[t]{2}{*}{$\begin{array}{l}\text { IPOs on } \\
\text { Exchange-reg. } \\
\text { markets } \\
\text { (D) } \\
0.112\end{array}$} & \multicolumn{2}{|c|}{$\begin{array}{c}(\mathrm{A})-(\mathrm{C}) \\
(\mathrm{E}) \\
\end{array}$} & \multicolumn{2}{|c|}{$\begin{array}{c}(\mathrm{B})-(\mathrm{D}) \\
(\mathrm{F}) \\
\end{array}$} \\
\hline & & & & & $0.034 *$ & (1.64) & $-0.052 * * *$ & $(-2.94)$ \\
\hline Offer_size & 1.154 & 1.423 & 0.874 & 0.866 & $0.280 * * *$ & $(5.04)$ & $0.557 * * *$ & $(7.40)$ \\
\hline Integer_offerprice & 0.259 & 0.465 & 0.194 & 0.169 & $0.064 * *$ & $(2.22)$ & $0.296 * * *$ & $(8.15)$ \\
\hline Bookbuilt & 0.478 & 0.862 & 0.611 & 0.599 & $-0.133 * * *$ & $(-3.93)$ & $0.264 * * *$ & (7.38) \\
\hline Firm_commitment & 0.398 & 0.100 & 0.059 & 0.061 & $0.339 * * *$ & $(11.80)$ & $0.040 *$ & $(1.78)$ \\
\hline Equity_carveout & 0.025 & 0.019 & 0.009 & 0.010 & $0.016^{*}$ & $(1.67)$ & 0.009 & $(0.93)$ \\
\hline Underwriter_rep & 0.132 & 0.242 & 0.046 & 0.045 & $0.085 * * *$ & $(4.15)$ & $0.197 * * *$ & $(7.22)$ \\
\hline \# of observations & 638 & 269 & 324 & 314 & & & & \\
\hline
\end{tabular}

This table provides univariate comparisons of the firms included in our correct treatment sample (Column (D) of Table 1) and the firms that are excluded from the correct treatment sample (Column (C) in Table 1). Correct sample (Column A) consist of IPOs listed on EU-regulated markets (Column B) and those listed on non-EU countries, i.e., Australia, Hong Kong, South Africa, and Philippines (not analyzed in this table). IPOs excluded from the Full Sample (Column C) consist of those listed on exchange-regulated markets (Column D) and Swiss IPOs (not analyzed in this table). Column E reports the mean difference between the Correct Sample (Column A) and all IPO excluded from the correct sample (Column C). Column F reports the mean difference between IPOs listing on EU-regulated markets (Column B) and those listing on exchange-regulated markets (Column D). All variables are defined in the endnotes of Table 3. Significance levels at $10 \%$, $5 \%$, and $1 \%$, two-tailed, are indicated by $*, * *$, and $* * *$, respectively. 
Table 3: Estimating Equation (1) for Both Full Sample and Correct Sample

\begin{tabular}{|c|c|c|c|c|c|c|c|c|c|c|c|c|}
\hline \multirow[b]{3}{*}{ Post } & \multicolumn{6}{|c|}{ Full Sample } & \multicolumn{6}{|c|}{ Correct Sample } \\
\hline & \multicolumn{2}{|c|}{$\begin{array}{l}\text { Benchmark Sample } \\
=\text { PS-matched } \\
\text { non-IFRS IPOs } \\
\text { (A) }\end{array}$} & \multicolumn{2}{|c|}{$\begin{array}{l}\text { Benchmark Sample } \\
=\text { PS-matched } \\
\text { non-US non-IFRS } \\
\text { IPOs } \\
\text { (B) }\end{array}$} & \multicolumn{2}{|c|}{$\begin{array}{c}\text { Benchmark } \\
\text { Sample = Canada, } \\
\text { Japan, and US } \\
\text { IPOs } \\
\text { (C) }\end{array}$} & \multicolumn{2}{|c|}{$\begin{array}{l}\text { Benchmark Sample } \\
=\text { PS-matched } \\
\text { non-IFRS IPOs } \\
\text { (D) }\end{array}$} & \multicolumn{2}{|c|}{$\begin{array}{l}\text { Benchmark Sample } \\
=\text { PS-matched } \\
\text { non-US non-IFRS } \\
\text { IPOs } \\
\text { (E) }\end{array}$} & \multicolumn{2}{|c|}{$\begin{array}{c}\text { Benchmark Sample } \\
=\text { Canada, Japan, } \\
\text { and US IPOs } \\
\text { (F) }\end{array}$} \\
\hline & $-0.557 *$ & $(-1.94)$ & $-0.510 *$ & $(-1.88)$ & -0.539 & $(-1.02)$ & $-0.473 * * *$ & $(-3.19)$ & $-0.380 * *$ & $(-2.24)$ & -0.538 & $(-0.98)$ \\
\hline$I F R S$ & 0.384 & $(1.21)$ & 0.169 & $(0.70)$ & 0.567 & $(0.82)$ & 0.241 & $(0.92)$ & -0.080 & $(-0.32)$ & 0.562 & $(0.77)$ \\
\hline Post $\times$ IFRS & $-0.695 * *$ & $(-2.27)$ & $-0.504 *$ & $(-1.83)$ & $-1.353 *$ & $(-1.78)$ & -0.532 & $(-1.66)$ & -0.206 & $(-0.64)$ & -1.292 & $(-1.65)$ \\
\hline Offer_size & $-0.150 * *$ & $(-2.67)$ & $-0.152 * *$ & $(-2.71)$ & $-0.165^{* *}$ & $(-2.17)$ & $-0.213 * * *$ & $(-3.17)$ & $-0.216^{* * *}$ & $(-3.32)$ & $-0.236^{* * *}$ & $(-3.23)$ \\
\hline Integer_offerprice & 0.056 & $(1.22)$ & 0.064 & $(1.54)$ & -0.050 & $(-1.19)$ & 0.014 & $(0.28)$ & 0.042 & $(0.81)$ & -0.039 & $(-0.71)$ \\
\hline Bookbuilt & 0.069 & $(1.24)$ & $0.089 *$ & (1.93) & $0.091 * *$ & $(2.09)$ & 0.045 & $(0.59)$ & 0.048 & $(0.76)$ & $0.075^{*}$ & $(1.95)$ \\
\hline Firm_commitment & -0.046 & $(-0.79)$ & -0.012 & $(-0.27)$ & -0.031 & $(-0.67)$ & -0.048 & $(-0.75)$ & -0.014 & $(-0.29)$ & -0.018 & $(-0.45)$ \\
\hline Equity_carveout & 0.049 & $(0.98)$ & 0.027 & $(0.48)$ & -0.006 & $(-0.11)$ & 0.027 & $(0.49)$ & 0.027 & $(0.55)$ & 0.012 & $(0.23)$ \\
\hline Underwriter_rep & 0.041 & $(0.86)$ & 0.017 & $(0.35)$ & 0.003 & $(0.10)$ & 0.091 & $(1.38)$ & 0.070 & $(0.97)$ & 0.035 & $(1.35)$ \\
\hline Country_q & -0.093 & $(-0.86)$ & -0.009 & $(-0.12)$ & $-0.267 * * *$ & $(-4.63)$ & -0.108 & $(-1.08)$ & -0.012 & $(-0.16)$ & $-0.269 * * *$ & $(-3.66)$ \\
\hline Market_return & 0.002 & $(0.06)$ & -0.011 & $(-0.30)$ & 0.066 & $(0.67)$ & -0.001 & $(-0.02)$ & -0.006 & $(-0.15)$ & 0.065 & $(0.66)$ \\
\hline Market_turnover & 0.046 & $(0.28)$ & 0.224 & $(1.37)$ & $-0.332 * * *$ & $(-5.31)$ & 0.061 & $(0.33)$ & 0.178 & $(1.05)$ & $-0.360 * * *$ & $(-4.97)$ \\
\hline Price_stabilization & 0.706 & $(1.02)$ & 0.863 & (1.11) & -0.266 & $(-0.52)$ & 0.016 & $(0.03)$ & 0.198 & $(0.29)$ & -0.682 & $(-0.99)$ \\
\hline Economic freedom & 0.001 & $(0.30)$ & 0.004 & $(0.96)$ & -0.007 & $(-1.48)$ & -0.001 & $(-0.30)$ & 0.001 & $(0.18)$ & $-0.007^{*}$ & $(-1.82)$ \\
\hline Earnings_opacity & 0.006 & $(1.48)$ & 0.005 & (1.40) & $0.010 * *$ & $(2.31)$ & 0.004 & $(0.83)$ & 0.003 & $(0.77)$ & 0.007 & $(1.61)$ \\
\hline Rule_of_law & 0.124 & $(1.47)$ & 0.080 & $(1.06)$ & $0.191 * * *$ & (3.09) & $0.165^{*}$ & (1.99) & 0.125 & $(1.59)$ & $0.204 * *$ & $(2.73)$ \\
\hline IPO activity & $1.163 * *$ & $(2.62)$ & $1.118 * *$ & $(2.66)$ & $2.041 * * *$ & $(5.33)$ & $0.923^{*}$ & $(2.00)$ & 0.626 & $(1.49)$ & $2.112 * * *$ & (4.63) \\
\hline Foreign_equity_inv & 0.002 & $(0.10)$ & 0.003 & $(0.16)$ & -0.009 & $(-0.47)$ & -0.004 & $(-0.23)$ & 0.004 & $(0.20)$ & 0.001 & $(0.06)$ \\
\hline Global_q & $-2.673 * *$ & $(-2.18)$ & $-2.100 *$ & $(-1.95)$ & -4.151 & $(-1.53)$ & $-1.990 * *$ & $(-2.14)$ & -0.967 & $(-1.11)$ & -4.073 & $(-1.44)$ \\
\hline Year & $0.292 * *$ & $(2.17)$ & $0.233^{*}$ & $(1.93)$ & 0.457 & $(1.55)$ & $0.256^{* *}$ & $(2.65)$ & 0.157 & $(1.42)$ & 0.455 & $(1.49)$ \\
\hline Industry fix. eff. & \multicolumn{2}{|c|}{ Yes } & \multicolumn{2}{|c|}{ Yes } & \multicolumn{2}{|l|}{ Yes } & \multicolumn{2}{|c|}{ Yes } & \multicolumn{2}{|c|}{ Yes } & \multicolumn{2}{|c|}{ Yes } \\
\hline Adjusted std. errors & \multicolumn{2}{|c|}{ Yes } & \multicolumn{2}{|c|}{ Yes } & \multicolumn{2}{|c|}{ Yes } & \multicolumn{2}{|c|}{ Yes } & \multicolumn{2}{|c|}{ Yes } & \multicolumn{2}{|c|}{ Yes } \\
\hline Adjusted $\mathrm{R}^{2}$ & \multicolumn{2}{|c|}{$13.63 \%$} & \multicolumn{2}{|c|}{$15.34 \%$} & \multicolumn{2}{|c|}{$22.37 \%$} & \multicolumn{2}{|c|}{$17.48 \%$} & \multicolumn{2}{|c|}{$18.55 \%$} & \multicolumn{2}{|c|}{$22.86 \%$} \\
\hline \# of observations & \multicolumn{2}{|c|}{2,848} & \multicolumn{2}{|c|}{2,848} & \multicolumn{2}{|c|}{2,714} & 2,20 & & 2,20 & & 2,3 & \\
\hline
\end{tabular}

This table presents the results of estimates of Equation (1) using both our Full Sample (which is not corrected for the sampling error identified in HHL's study) and our Correct Sample (which is corrected for the effect of the sampling error we identify in HHL's study). For each treatment sample (the Full Sample and the Correct Sample), consistent with HHL, we estimate Equation (1) using three different benchmark samples. The three benchmark samples are: (Columns A and D) a one-to-one PS matched benchmark sample drawn from all non-IFRS adopting countries; (Columns B and E) a one-to-one PS matched benchmark sample of IPOs 
based in all non-IFRS adopting countries, except the U.S.; and (Columns C and F) a benchmark sample consisting of all IPOs over this sample period in three developed countries, specifically, the U.S., Canada, and Japan (this latter benchmark sample is not one-to-one matched with the treatment sample). The results using the Full Sample, which is not corrected for the effects of HHL's sampling error, are shown in Columns (A) to (C). The results using the Correct Sample, which is corrected for the effects of HHL's sampling error, are shown in Columns (D) to (F). Standard errors are adjusted by country of listing. Significance levels at $10 \%, 5 \%$, and $1 \%$, two-tailed, are indicated by $* * *$, and $* * *$, respectively.

\section{Variable Definitions (as defined in Appendix A of HHL):}

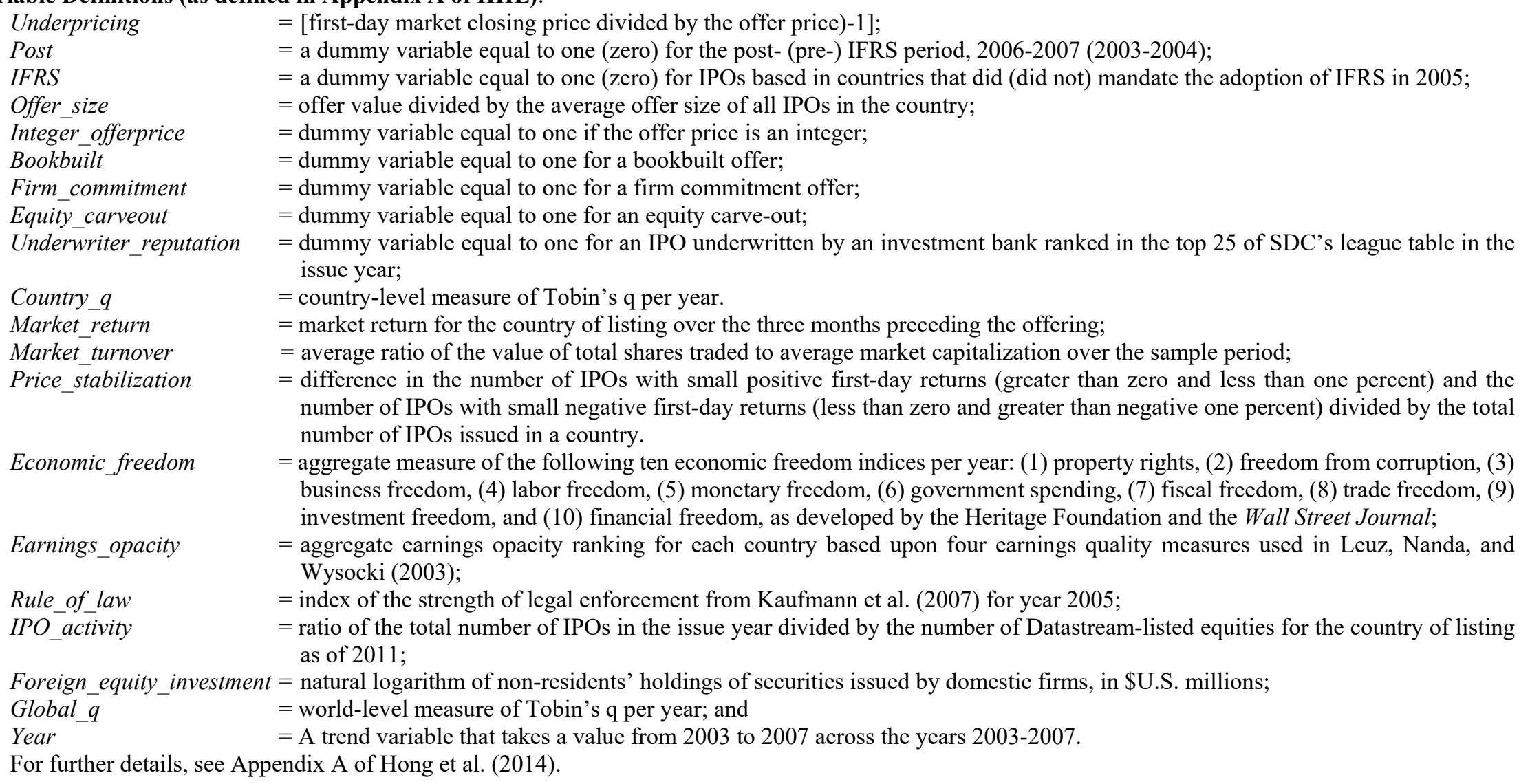


Table 4: Sample Selection for Test of Joint Effect of IFRS and PD Adoptions

\section{Panel A: Sample Selection}

EU IPOs listed between 3/15/04 and 3/28/08, excluding investment offices (SIC = 67)

(IPOs listing on exchange-regulated markets)

(Unavailable variables)

(Country-industry pairs with no IFRS-reporting IPOs or no GAAP-reporting IPOs, or with no

IPOs during pre-PD or no IPOs during the post-PD period)

Final Sample

Panel B: Sample composition

\begin{tabular}{|c|c|c|c|c|c|c|}
\hline \multirow[b]{2}{*}{ Country } & \multirow[b]{2}{*}{ PD effective date } & \multirow[b]{2}{*}{ Industry } & \multicolumn{2}{|c|}{$\begin{array}{c}\text { \# IPOs by } \\
\text { PD }\end{array}$} & \multicolumn{2}{|c|}{$\begin{array}{l}\text { \# IPOs by } \\
\text { Acct. Stds. }\end{array}$} \\
\hline & & & $\begin{array}{l}\text { Pre- } \\
\text { PD }\end{array}$ & $\begin{array}{l}\text { Post- } \\
\text { PD }\end{array}$ & GAAP & IFRS \\
\hline Belgium & July 1, 2006 & Utilities industry & 3 & 1 & 2 & 2 \\
\hline Finland & July 1,2005 & Basic industry & 1 & 2 & 1 & 2 \\
\hline \multirow[t]{7}{*}{ France } & July 27,2005 & Basic industry & 1 & 7 & 1 & 7 \\
\hline & & Consumer durables industry & 4 & 4 & 3 & 5 \\
\hline & & Construction industry & 2 & 1 & 2 & 1 \\
\hline & & Finance/real estate industry & 1 & 11 & 6 & 6 \\
\hline & & Leisure industry & 1 & 2 & 1 & 2 \\
\hline & & Service industry & 2 & 8 & 2 & 8 \\
\hline & & Utilities industry & 2 & 6 & 2 & 6 \\
\hline \multirow[t]{2}{*}{ Germany } & July 1, 2005 & Consumer durables industry & 3 & 14 & 3 & 14 \\
\hline & & Service industry & 1 & 11 & 1 & 11 \\
\hline \multirow[t]{2}{*}{ Italy } & March 29, 2007 & Capital goods industry & 4 & 1 & 1 & 4 \\
\hline & & Textiles/trade industry & 4 & 2 & 1 & 5 \\
\hline \multirow[t]{5}{*}{ Norway } & January 1,2006 & Basic industry & 2 & 5 & 1 & 6 \\
\hline & & Capital goods industry & 1 & 3 & 1 & 3 \\
\hline & & Finance/real estate industry & 1 & 2 & 2 & 1 \\
\hline & & Petroleum industry & 4 & 4 & 6 & 2 \\
\hline & & Service industry & 7 & 7 & 4 & 10 \\
\hline Netherlands & July 1, 2005 & Consumer durables industry & 1 & 1 & 1 & 1 \\
\hline \multirow[t]{7}{*}{ Poland } & October 24,2005 & Basic industry & 2 & 1 & 2 & 1 \\
\hline & & Consumer durables industry & 1 & 5 & 4 & 2 \\
\hline & & Capital goods industry & 1 & 4 & 2 & 3 \\
\hline & & Finance/real estate industry & 2 & 5 & 1 & 6 \\
\hline & & Food/tobacco industry & 3 & 6 & 4 & 5 \\
\hline & & Leisure industry & 2 & 1 & 1 & 2 \\
\hline & & Textiles/trade industry & 1 & 6 & 3 & 4 \\
\hline Portugal & March 30, 2006 & Utilities industry & 1 & 1 & 1 & 1 \\
\hline \multirow[t]{2}{*}{ Spain } & March 15, 2005 & Construction industry & 1 & 1 & 1 & 1 \\
\hline & & Finance/real estate industry & 1 & 7 & 2 & 6 \\
\hline Sweden & July 1,2005 & Consumer durables industry & 1 & 5 & 3 & 3 \\
\hline \multirow[t]{5}{*}{ UK } & July 1,2005 & Basic industry & 3 & 13 & 5 & 11 \\
\hline & & Consumer durables industry & 3 & 3 & 3 & 3 \\
\hline & & Capital goods industry & 2 & 3 & 2 & 3 \\
\hline & & Finance/real estate industry & 5 & 8 & 6 & 7 \\
\hline & & Food/tobacco industry & 1 & 4 & 3 & 2 \\
\hline
\end{tabular}




\begin{tabular}{|c|c|c|c|c|c|}
\hline & Leisure industry & 1 & 2 & 2 & 1 \\
\hline & Petroleum industry & 2 & 1 & 2 & 1 \\
\hline & Service industry & 10 & 11 & 12 & 9 \\
\hline & Textiles/trade industry & 4 & 3 & 5 & 2 \\
\hline & Utilities industry & 4 & 2 & 5 & 1 \\
\hline Total & & 96 & 184 & 107 & 173 \\
\hline
\end{tabular}

This table shows the selection (Panel A) and country distribution (Panel B) of our sample of 280 IPOs on EU-regulated markets over the period 2006-2007. Panel A shows that we begin by retrieving 1,797 IPOs with available data from SDC for the period beginning one year prior to the first adoption of the PD in Spain to one year after the last adoption of the PD in Italy. The PD was adopted on March 15, 2005 in Spain and March 29, 2007, in Italy. Our sample period, therefore, spans between 3/15/04 and 3/28/08. We do not include firms with SIC codes beginning with 67, to exclude investment offices and unit trusts. We further exclude 1,053 IPOs listing on exchange-regulated markets, and 584 IPOs with unavailable variables. We also exclude 304 IPOs in country-industry pairs in which there is no matched IPO in the same industry-country during the pre- or post-PD period, or in which there is no IFRS- or domestic GAAPreporting IPO in an industry-country. The final sample consists of 280 European IPOs listing on EU-regulated markets, which is balanced, with respect to country and industry, between before- and after-PD period and between IFRS- and GAAP-reporting firms. Firms' accounting standards are identified as the accounting standards used in the last fiscal year's data before the IPO date, according to Worldscope. For 2005, the data is hand-collected if Worldscope data indicates that the firm was using domestic GAAP for the last year's financial data. Panel B shows the country distribution of the sample. 
Table 5: Joint Test of Effects of IFRS and PD Adoption, and Increased Accounting Enforcement

\begin{tabular}{|c|c|c|c|c|c|c|}
\hline & \multicolumn{2}{|c|}{ GAAP versus IFRS } & \multicolumn{2}{|c|}{ Pre- versus Post-PD } & \multicolumn{2}{|c|}{ Full Model } \\
\hline & Model (1) & Model (2) & Model (3) & Model (4) & Model (5) & Model (6) \\
\hline \multirow[t]{2}{*}{ IFRS } & 0.008 & 0.033 & & & -0.004 & 0.031 \\
\hline & $(0.06)$ & $(0.28)$ & & & $(-0.04)$ & $(0.30)$ \\
\hline \multirow[t]{2}{*}{$I F R S \times E n f$} & & -0.082 & & & & 0.426 \\
\hline & & $(-0.40)$ & & & & $(1.22)$ \\
\hline \multirow[t]{2}{*}{$P D$} & & & -0.207 & -0.094 & -0.229 & 0.103 \\
\hline & & & $(-1.04)$ & $(-0.51)$ & $(-0.76)$ & $(0.46)$ \\
\hline \multirow[t]{2}{*}{$P D \times E n f$} & & & & $-0.330^{*}$ & & $-0.682 * *$ \\
\hline & & & & $(-1.71)$ & & $(-2.11)$ \\
\hline \multirow[t]{2}{*}{$P D \times I F R S$} & & & & & 0.036 & -0.217 \\
\hline & & & & & $(0.18)$ & $(-1.17)$ \\
\hline \multirow[t]{2}{*}{ Offer_Size } & $-0.230^{* *}$ & $-0.223^{* *}$ & $-0.219^{* *}$ & $-0.184^{*}$ & $-0.219^{* *}$ & $-0.194^{*}$ \\
\hline & $(-2.48)$ & $(-2.38)$ & $(-2.27)$ & $(-1.87)$ & $(-2.20)$ & $(-1.89)$ \\
\hline \multirow[t]{2}{*}{ Bookbuilt } & -0.415 & -0.415 & -0.423 & -0.433 & -0.426 & -0.436 \\
\hline & $(-0.83)$ & $(-0.82)$ & $(-0.84)$ & $(-0.86)$ & $(-0.82)$ & $(-0.85)$ \\
\hline \multirow[t]{2}{*}{ MktRet } & -1.063 & -1.072 & -1.036 & -1.087 & -1.038 & -1.151 \\
\hline & $(-0.71)$ & $(-0.71)$ & $(-0.69)$ & $(-0.70)$ & $(-0.69)$ & $(-0.74)$ \\
\hline Fixed effects & $\begin{array}{l}\text { Country } \times \text { ind } \\
\& \text { year }\end{array}$ & $\begin{array}{c}\text { Country } \times \text { ind } \\
\& \text { year }\end{array}$ & $\begin{array}{l}\text { Country } \times \text { ind } \\
\& \text { year }\end{array}$ & $\begin{array}{l}\text { Country } \times \text { ind } \\
\& \text { year }\end{array}$ & $\begin{array}{c}\text { Country } \times \text { ind } \\
\& \text { year }\end{array}$ & $\begin{array}{c}\text { Country } \times \text { ind } \\
\& \text { year }\end{array}$ \\
\hline \multirow[t]{2}{*}{ Adj. std. err. } & Country & Country & Country & Country & Country & Country \\
\hline & \& year & \& year & \& year & \& year & $\&$ year & $\&$ year \\
\hline Adjusted $\mathrm{R}^{2}$ & $7.40 \%$ & $7.04 \%$ & $7.58 \%$ & $7.67 \%$ & $6.79 \%$ & $6.82 \%$ \\
\hline \# of obs. & 280 & 280 & 280 & 280 & 280 & 280 \\
\hline
\end{tabular}

This table presents the results of estimates of different versions of Equation (3), which tests the joint effect of IFRS and PD adoption on IPO firms listing on EU-regulated markets. IFRS is an indicator variable equal to one (zero) if the IPO is after (before) mandatory IFRS adoption. $P D$ is an indicator variable equal to one if an IPO is listing after the listing country adopts PD into its national law, and zero otherwise. Enf equals one if an IPO is listing after the end of a quarter when the listing country enforces its securities law (Finland 2005 Q1, Germany 2005 Q4, the Netherlands 2005 Q4, Norway 2005 Q4, and UK 2005 Q2; see Christensen et al. 2013), and zero otherwise. When the sample is balanced with respect to industry and country, the dummy variables that represent each effect (PD, IFRS, and Enf) together with fixed effects for industry-country pairs are expected to capture changes around each effect when country and industry substantially affect the level of IPO underpricing. Further, we control for offer size (Offer_Size as defined in Table 3), whether the underwriter is using a book-building technique offer, (Bookbuilt), and cumulative return during 90 days before the IPO date of the Datastream market index a country (MktRet). Considering the nature of small sample size with a number of fixed effects, we decide not to use the other variables that are used in HHL's analysis but of less influential. Other than industry-country pair fixed effects, year fixed effects are included. Standard errors are clustered at the country and year level. Significance levels at $10 \%, 5 \%$, and $1 \%$, two-tailed, are indicated by $*, * *$, and ${ }^{* * *}$, respectively. 
Table 6: Voluntary IFRS Adoptions by IPO Firms Admitted to Trading on Exchange-Regulated Markets After 2005

\begin{tabular}{lc} 
Panel A. Sample Section & No. of IPO Firms \\
\hline EU IPOs, excluding investment offices (SIC = 67), in period 2006-2007 & 1,441 \\
$\quad$ (Listings on EU-regulated markets or AIM in 2007) & $(818)$ \\
$\quad$ (Unavailable variables) & $(199)$ \\
(Countries with one or more domestic GAAP and no IFRS firms, or vice versa ) & $(5)$ \\
\hline Final Sample & 419 \\
\hline
\end{tabular}

Panel B. Sample Composition

\begin{tabular}{lcc}
\hline Country & Domestic GAAP & IFRS \\
\hline Belgium & 8 & 2 \\
Denmark & 7 & 2 \\
France & 93 & 7 \\
Germany & 23 & 8 \\
Sweden & 4 & 3 \\
UK $^{1}$ & 167 & 95 \\
\hline Total & 302 & 117 \\
\hline
\end{tabular}

Panel C. Choice of IFRS against GAAP

\begin{tabular}{|c|c|c|c|c|}
\hline & \multicolumn{2}{|c|}{$\begin{array}{l}\text { IFRSNetworkSize Measured as the } \\
\text { Proportion of Domestic Industry Peers } \\
\text { Reporting in IFRS }\end{array}$} & \multicolumn{2}{|c|}{$\begin{array}{l}\text { IFRSNetworkSize Measured as the } \\
\text { Proportion of Global Industry Peers } \\
\text { Reporting in IFRS }\end{array}$} \\
\hline & Coeff. & t-stat. & Coeff. & t-stat. \\
\hline IFRSNetworkSize & $1.343^{*}$ & $(1.90)$ & 1.271 & $(1.07)$ \\
\hline Offer_Size & $0.360 * *$ & $(2.34)$ & $0.378 * *$ & $(2.42)$ \\
\hline Cross & $0.962 * * *$ & (20.16) & $0.990 * * *$ & (20.40) \\
\hline Fixed effects & \multicolumn{2}{|c|}{ Country \& year } & \multicolumn{2}{|c|}{ Country \& year } \\
\hline Adj. std. err. & \multicolumn{2}{|c|}{ Country \& year } & \multicolumn{2}{|c|}{ Country \& year } \\
\hline Adjusted $\mathrm{R}^{2}$ & \multicolumn{2}{|c|}{$34.00 \%$} & \multicolumn{2}{|c|}{$33.01 \%$} \\
\hline \# of obs. & \multicolumn{2}{|c|}{419} & \multicolumn{2}{|c|}{419} \\
\hline
\end{tabular}

${ }^{1}$ The Alternative Investments Market (AIM), the main exchange-regulated market in the UK adopted IFRS as a listing requirement from 1/1/2007. Accordingly, for the UK, we include only data for 2006.

This table shows the results of an analysis of voluntary IFRS adoptions by firms admitted to trading on exchangeregulated markets in 2006-2007. Panel A shows the sample selection. Panel B shows the distributions of firms using domestic GAAP and IFRS, by country. Finally, Panel C reports the results of estimates of a probit model (Equation (3)) that tests the association between the probability that an IPO firm admitted to trading on an exchange-regulated market voluntarily chooses to use IFRS rather than domestic GAAP and the relative size of that firm's potential IFRS reporting network. The dependent variable is an indicator variable coded one (zero) if an IPO firm uses IFRS (domestic GAAP). The variable of interest is IFRSNetworkSize, which is a proxy for the relative size of an IPO firm's potential IFRS "reporting network." We use two methods to measure IFRSNetworkSize: (1) the proportion of an IPO firm's domestic industry peers reporting in IFRS: (1+\#IFRS-reporting domestic industry peers)/(1+\#all domestic industry peers); and (2) as the proportion of an IPO firm's global industry peers reporting in IFRS: (1+\#IFRS-reporting global industry peers)/(1+\#all global industry peers). We use Worldscope data to measure the number of listed industry peers using IFRS and domestic GAAP are measured in the period from three months before an IPO's issue date until the issue date. Offer Size is offer value divided by the average offer size of all IPOs in the country. Cross is coded 1 if an IPO is listing outside of its home country; 0 otherwise. Country and year fixed effects are included. Standard errors are clustered at the country and year level. Significance levels at $10 \%, 5 \%$, and $1 \%$, two-tailed, are indicated by *, **, and $* * *$, respectively. 